\title{
WHAT'S LEFT TO REMEDY WAGE THEFT? HOW ARBITRATION MANDATES THAT BAR CLASS ACTIONS IMPACT LOW-WAGE WORKERS
}

\author{
Nantiya Ruan*
}

2012 MiCH. ST. L. REV. 1103

TABLE OF CONTENTS

INTRODUCTION

I. WAGE THEFT IN AMERICA

A. Low-Wage Work: Impacting the Most Vulnerable

B. Under-Enforcement by Regulatory Agencies and the Barriers to Private Enforcement

II. The Role of Class Actions in Protecting Against Wage THEFT.

A. The Difficulties in Prosecuting Small Wage Claims ..................1118

B. The Threat of Retaliation.

C. The Importance of Notification Under 216(b).

D. Deterring Future Wage Theft

III. THE GROWTH OF MANDATORY ARBITRATION AND ClASS

WAIVERS IN EMPLOYMENT CONTEXTS

A. Judicial Enforcement: The FAA

B. Class Waivers: Banning Aggregate Claims

1. When Silence in Contracts Is Given Legal Meaning

2. AT\&T Mobility LLC v. Concepcion: Protecting Defendants from Collective Action.

3. The Post-Concepcion Split.

IV. HOW MANDATORY ARBITRATION WITH CLASS WAIVERS

AFFECTS LOW-WAGE WORKERS: WHERE DO WE GO FROM HERE? 1136

A. Redress Within the Current System of Enforcement

1. Challenging Class Waivers as Precluding Vindication of Federal Statutory Rights.

2. Renewed Public Enforcement of Wage Rights

* J.D., M.S.W., Lawyering Process Professor, Director of Workplace Law Program, University of Denver Sturm College of Law. A special thank you to Rosemary Dillon, Piper Hoffman, Nancy Leong, Julie Nice, Nancy Reichman, as well as the Colorado Employment Law Faculty working group (particularly Professors Rachel Arnow-Richman, Melissa Hart, and Scott Moss) for their helpful feedback. This Article was made better by the comments given when presented at the Law \& Society Association Conference in Hawaii, May 2012, and the Labor and Employment Law Scholarship Colloquium, held in Los Angeles in September 2011. Special thanks to Joseph Doyle for his excellent research assistance. 
B. Changing the Forum to Fit the Need

1. Making Arbitration Work for Low-Wage Workers 1141

2. Wage Claims Court......................................................1144

CONCLUSION 1146

\section{INTRODUCTION}

Suppose that a retail worker making slightly above minimum wage is asked by her supervisor to come in early but not clock in until her shift is scheduled to begin. She is also asked to stay late, even though her babysitter is expecting her home, and to finish putting the clothes from the dressing rooms back on the racks before she leaves, but only after she clocks out. Imagine also that her manager tells her that yes, she can take her mandated lunch hour, but it would be better for her if she were to check and clean the bathrooms before she sat down to eat. Also, if she wants to keep her job, the forty-five hours she worked will be reflected on her time card as forty so that the store will not have to pay her premium overtime pay for those five extra hours, and thus keep within the company's strict payroll budget. She's told that the store will make it up to her next quarter, but it never does. Will she be able to find a private attorney to help her recover the dollars she has coming to her? Are her federal or state Departments of Labor likely to investigate her complaint, even if she was knowledgeable enough to make such a claim?

Off-the-clock work, meal and overtime violations, and time shaving are all part of a pervasive wage theft problem facing American workers. Unscrupulous employers seek to survive and thrive in business by keeping payroll costs low through these and other unlawful wage practices. The law in this area is broad and clear: the federal Fair Labor Standards Act of 1938 requires that all workers (save the few covered by a small number of specific enumerated exceptions) must be paid minimum wage and overtime pay for all hours worked for the benefit of their employers. ${ }^{1}$ Moreover, various state wage and hour laws provide further redress against off-the-clock work such as that described above. However, public enforcement of these legal mandates has been lacking for years, and private enforcement has come under recent attack by the U.S. Supreme Court.

Because of high transaction costs and relatively low potential damages, the worker in the above example is likely to recover her lost wages only if she bands together with similarly-situated workers in an aggregate lawsuit against her employer. However, this type of collective action is under attack: AT\&T Mobility LLC v. Concepcion is the latest Supreme Court case to examine the viability of mandatory arbitration clauses that prohibit class

1. 29 U.S.C. $\S \S 201,206,207$ (2006). 
actions, and in a sharply divided opinion, it determined that mandating individual arbitration is consistent with federal labor policy. ${ }^{2}$

This Article brings new insights into the Supreme Court's widening blind spot regarding the impact procedural rules have on the substantive rights of low-wage workers. Moreover, it touches upon a greater trend in American jurisprudence of courts "closing the courtroom doors" tiffs, especially those unlikely to afford legal representation. By drawing attention to the unjust effects of facially neutral rules on poor workers, this Article contributes to the national conversation on how Supreme Court precedent limiting judicial access affects the most vulnerable in our society.

Much scholarly attention has been given to the debate on the appropriateness of mandating arbitration, especially amongst employers and employees, with its attendant bargaining and power inequities. ${ }^{4}$ However, the literature thus far has failed to capture the rest of the story: it's not just about the forced nature of arbitration but also about whether the forum can fit the needs of vulnerable and poor parties. Moreover, the focus on employment arbitration is mostly centered on employment discrimination and the difficulties of arbitration as a forum for complex burden-shifting liability. But wage claims are significantly different and bring a different set of considerations that must be addressed when evaluating the benefits and burdens of the arbitration forum.

At first blush, merely changing the forum from public litigation to private arbitration would seem not to affect the ability of low-wage workers to vindicate their statutory wage rights. But, as this Article explains, several factors effectively incentivize unscrupulous employers to profit off the backs of low-wage workers: unfettered arbitration mandates, prohibitions on aggregating claims, anemic regulation and public enforcement of wages, and high transactional costs. These factors combine to close the doors of justice on low-wage workers.

In Part I, wage theft as a persistent national epidemic is discussed, including the most recent studies on low-wage work and the trend in litigating statutory wage rights. Also, this section looks at the under-enforcement of

2. 131 S. Ct. 1740 (2011).

3. Erwin Chemerinsky, Closing the Courthouse Doors, 90 DENV. U. L. REV. (forthcoming 2013).

4. See, e.g., Bradley Dillon-Coffman, Comment, Revising the Revision: Procedural Alternatives to the Arbitration Fairness Act, 57 UCLA L. REv. 1095, 1096-97 (2010); Daniel B. Klaff, Debiasing and Bidirectional Bias: Cognitive Failure in Mandatory Employment Arbitration, 15 Harv. Negot. L. Rev. 1 (2010); Michael H. LeRoy \& Peter Feuille, When Is Cost an Unlawful Barrier to Alternative Dispute Resolution? The Ever Green Tree of Mandatory Employment Arbitration, 50 UCLA L. REV. 143 (2002); Theodore J. St. Antoine, Mandatory Employment Arbitration: Keeping It Fair, Keeping It Lawful, 60 CASE W. RES. L. REV. 629 (2010). 
our country's wage protections and employer incentives for violating the FLSA.

In Part II, this Article examines the role class actions play in vindicating wage rights for low-wage workers. Because of the high transaction costs and relatively low individual damages at stake, aggregation of claims is often the only vehicle by which to vindicate statutory wage rights. Collective actions also have the advantage of protecting vulnerable workers from drawing attention to their individual participation and subjecting them to retaliatory measures. Additionally, collective actions increase awareness of workplace violations and increase the cost of non-compliance, which benefits both workers and responsible employers who would otherwise be at a disadvantage in their competition with wage violators.

Part III explores the doctrine of mandatory arbitration and class waivers, including the most recent trends in the arbitrability of federal wage and hour laws. Judicial enforcement of arbitration agreements has widened considerably over the last several decades, culminating in a recent Supreme Court decision, AT\&T Mobility $L L C$ v. Concepcion, ${ }^{5}$ which muddied the already unclear waters of class arbitration. This section looks carefully at the Concepcion decision and its progeny to help foresee the future of wage collective actions.

Part IV summarizes the "search for the silver lining," asking where low-wage workers should go from here and proposing four plans for combating wage theft. The first two paths involve redress for wage theft within the current enforcement and regulatory system with strategies addressing the current judicial climate. The second two proposals involve changing the arbitral forum to fit the need of low-wage workers, including a broader role for worker centers and unions, changing unauthorized practice of law rules, and developing specialized courts to address wage theft.

\section{WAGE THEFT IN AMERICA}

"Wage theft" has become the twenty-first century moniker for a variety of wage and hour violations faced by low-wage workers in today's workplace. ${ }^{6}$ Unpaid minimum wages, misclassification of workers as "salaried" and therefore ineligible for overtime, "off-the-clock" work (such as pre- and post-shift unpaid work and work through mandatory unpaid breaks), illegal

5. 131 S. Ct. 1740.

6. See, e.g., Kim Bobo, Wage TheFt in America: Why Millions of Working Americans Are Not Getting Paid-and What We Can Do About It (2d ed. 2011); Nancy Reichman, What's in a Name? Wage Theft and the Criminalization of Unfair Labor Practices (2012) (unpublished manuscript) (on file with author); Brishen Rogers, Toward ThirdParty Liability for Wage Theft, 31 BERKELEY J. EMP. \& LAB. L. 1 (2010); Nantiya Ruan, Facilitating Wage Theft: How Courts Use Procedural Rules to Undermine Substantive Rights of Low-Wage Workers, 63 VAND. L. REV. 727 (2010). 
deductions, failure to pay final paychecks-these unlawful practices result in millions of dollars of lost money for workers who can least afford it. ${ }^{7}$ As witnessed by Dr. Nancy Reichman, a sociologist in the field, the number of scholarly articles and media reports studying the term "wage theft" first appeared in 2005 and has grown steadily since then. ${ }^{8}$ The rising number of lawsuits against major corporate employers is another indication that wage and hour violations portend a "crisis" for American workers. ${ }^{9}$ Claims by workers that their employers fail to pay them correctly have quadrupled over the last decade, increasing by $73 \%$ from 2006 to 2007 alone. $^{10}$

For over seven decades, the federal standard for unpaid wage claims has been the Fair Labor Standards Act of 1938 (FLSA). ${ }^{11}$ Following hearings in the 1930s, Congress found that the unregulated and substandard work conditions prevalent in Depression-era America negatively affected the "health, efficiency and general well-being" of workers, and enacted the FLSA. ${ }^{12}$ The FLSA establishes: (1) a minimum wage $;^{13}(2)$ a requirement of premium overtime pay for work exceeding forty hours in a workweek, $;^{14}(3)$ a prohibition on child labor; ${ }^{15}$ and (4) a mandate that employers keep accurate time records. ${ }^{16}$ Notably, seventy-four years post-enactment, the FLSA remains the primary wage protection law of our country. ${ }^{17}$ The fact that wage theft claims under the FLSA have seen such resurgence in the last decade suggests that protecting the well-being of low-wage workers remains a daunting challenge.

\section{A. Low-Wage Work: Impacting the Most Vulnerable}

One-quarter of all U.S. adults can be characterized as "low-wage workers," meaning they earn on average $\$ 27,000$ per year while working at

7. See ANNETte Bernhardt et al., Broken LaWs, UNPROTECTED Workers: VIOLATIONS OF EMPLOYMENT AND LABOR LAWS IN AMERICA'S CITIES 2-3 (2009).

8. Reichman, supra note 6 , at 4 ("The number of articles referencing 'wage theft' grew slowly after 2005 until 2009 when the number of articles referencing 'wage theft' exploded: eighty-three percent were written between 2009 and 2011.").

9. Ruan, supra note 6 , at 728 .

10. Id.

11. 29 U.S.C. $\$ 216(2006)$.

12. Carol Abdelmesseh \& Deanne M. DiBlasi, Note, Why Punitive Damages Should Be Awarded for Retaliatory Discharge Under the Fair Labor Standards Act, 21 HoFSTRA LAB. \& EMP. L.J. 715,719 (2004).

13. 29 U.S.C. $\$ 206(2006)$.

14. $I d . \S 207(\mathrm{a})(1)$.

15. Id. $\$ 212$.

16. Id. $\$ 211(\mathrm{c})$.

17. States can go above the federal "floor" in providing higher minimum wages, protecting against "spread of hours" abuses, and allowing lengthier statutes of limitations. See, e.g., State Minimum Wages, NAT'L Conf. ST. Legislatures (Jan. 1, 2013), http://www.ncsl.org/issues-research/labor/state-minimum-wage-chart.aspx. 
least thirty hours per week. ${ }^{18}$ Meanwhile, there is a growing gap between the top and bottom of the income ladder: in 2011, median household income for the bottom tenth of the income scale fell by $12 \%$ from a peak in 1999 , while the top ninetieth percentile dropped by only $1.5 \% .{ }^{19}$ The wage inequality of the working poor remains the largest threat Americans face in today's economy. ${ }^{20}$ Most scholarly attention and community advocacy for low-wage workers have focused on the most vulnerable within this category: the workplace abuses faced by immigrants. ${ }^{21}$ Those violations are severe and well-documented, including physical intimidation, ${ }^{22}$ harassment, ${ }^{23}$ and retaliation, ${ }^{24}$ as well as unpaid work.

But wage theft affects low-wage workers across industries and communities, not just within the immigrant population. Examples abound: the

18. Henry J. Kaiser family Found., Low-Wage Workers and Health Care 1 (2008), available at $\mathrm{http} / / \mathrm{www} . \mathrm{kff} .0 \mathrm{rg} / \mathrm{kaiserpolls/upload} / 7804 . \mathrm{pdf}$.

19. Sabrina Tavernise, Poverty Rate Soars to Highest Level Since 1993, N.Y. TIMES, Sept. 14, 2011, at A1; Carmen DeNavas-Walt, Bernadette D. Proctor \& Jessica C.

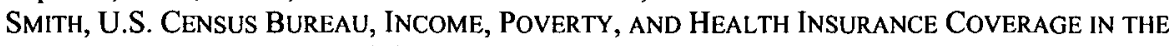
UNITED STATES: 2011 , at 11 (2012), available at http://www.census.gov/prod/2012pubs/p60243.pdf.

20. See generally Alan Hyde, Who Speaks for the Working Poor?: A Preliminary Look at the Emerging Tetralogy of Representation of Low-Wage Service Workers, 13 CORNELL J.L. \& PUB. POL'Y 599 (2004).

21. See, e.g., Nat'l EmP't Law Project, Winning Wage Justice: An Advocate's Guide to State and City Policies to Fight WAGE Theft 6 (2011), available at http://www.nelp.org/page/-/Justice/2011/WinningWageJustice2011.pdf?nocdn=1 [hereinafter NAT'L EMP'T LAW PROJECT, WINNING WAGE JUSTICE] (noting how immigrant workers are particularly at risk for wage theft); NAT'L EMP'T LAW PROJECT, UNINTENDED CONSEQUENCES: LIMITING WORKERS' COMPENSATION BENEFITS FOR UNDOCUMENTED WORKERS EXPOSES WORKERS TO GREATER RISKS OF INJURY, BUSINESS TO GREATER COSTS 1 (2011), available at $\mathrm{http}: / / \mathrm{nelp} .3 \mathrm{cdn} . n e t / \mathrm{f} 4626 \mathrm{~d} 080903865 \mathrm{~d} 3 \mathrm{e}$ _q7 $7 \mathrm{~m} 6 \mathrm{bn} 3 \mathrm{qp}$.pdf [hereinafter NAT'L EMP'T LAW PROJECT, UNINTENDED CONSEQUENCES] (discussing the state of the law regarding the marginalization of immigrant workers); Ruben J. Garcia, Ghost Workers in an Interconnected World: Going Beyond the Dichotomies of Domestic Immigration and Labor Laws, 36 U. MICH. J.L. REFORM 737, 753-54 (2003) (discussing the barriers created by U.S. law preventing immigrant workers from unionizing or improving work conditions). See generally RUBEN J. Garcia, Marginal Workers: How Legal Fault Lines Divide Workers AND Leave Them Without Protection (2012) (advocating for a new legal paradigm to protect marginalized immigrant workers).

22. Alvarado v. Shipley Donut Flour \& Supply Co., 526 F. Supp. 2d 746, 767 (S.D. Tex. 2007) (describing employers who brandished weapons to workers and routinely assaulted workers); Bureerong v. Uvawas, 922 F. Supp. 1450, 1459 (C.D. Cal. 1996) (alleging employer imprisoned Thai garment workers and assaulted them).

23. Chellen v. John Pickle Co., 446 F. Supp. 2d 1247, 1285 (N.D. Okla. 2006) (finding employer kept workers imprisoned and routinely harassed them about their Indian heritage).

24. Singh v. Jutla \& C.D. \& R's Oil, Inc., 214 F. Supp. 2d 1056, 1059-60 (N.D. Cal. 2002) (finding the employer fired workers after they filed a FLSA claim); Contreras v. Corinthian Vigor Ins. Brokerage, Inc., 25 F. Supp. 2d 1053, 1056-59 (N.D. Cal. 1998) (finding that FLSA applies to immigrant worker fired after he filed FLSA claim). 
cashiers at retail chains that are misclassified as "assistant managers" and lose thousands in unpaid overtime, ${ }^{25}$ restaurant workers who have their tips "reallocated" to owners and management ${ }^{26}$ truck drivers who have their hours shaved; ${ }^{27}$ car wash workers paid below minimum wage, ${ }^{28}$ temporary staffing agency workers who lose premium overtime pay through creative time keeping. ${ }^{29}$

The sheer breadth of claims brought by low-wage workers across industries and employer size is remarkable. Wal-Mart (the world's largest private employer) paid $\$ 352$ million dollars to settle sixty-three unpaid wages lawsuits in forty-two states, a settlement that still holds the record for the largest wage and hour settlement of all time. ${ }^{30}$ Bobby Flay, one of Amer-

25. Davis v. Wal Mart Stores, Inc., No. 3:10cv68 WHA, 2010 WL 3718834, at *7 (M.D. Ala. Sept. 13, 2010) (denying summary judgment to employer who classified worker whose duties were comprised of $90 \%$ non-managerial tasks as an assistant manager in order to avoid paying overtime); see also Jacob v. Duane Reade, Inc., No. 11 cv 0160 (JPO), 2012 WL 260230, at *10 (S.D.N.Y. Jan. 27, 2012) (certifying class of misclassified, assistant store managers whose duties were primarily non-managerial and who sued for back wages); In re Staples Inc. Wage \& Hour Emp't Practices Litig., No. 085746 (KSH), 2011 WL 5413221 (D.N.J. Nov. 4, 2011) (approving $\$ 42$ million settlement between misclassified assistant store managers and employer).

26. DeMunecas v. Bold Food, LLC, No. 09 Civ. 00440(DAB), 2010 WL 3322580, at*1 (S.D.N.Y. Aug. 23, 2010); Driver v. AppleIllinois, LLC, 265 F.R.D. 293, 299 (N.D. Ill. 2010) (certifying plaintiff's class and noting that the alleged employers "used money from the tip pool to make up for shortages in the cash register and to cover the bill of 'walk off' customers"); Ke v. Saigon Grill, Inc., 595 F. Supp. 2d 240, 257 (S.D.N.Y. 2008) (deducting tips taken from delivery drivers from wages because employer took money to compensate kitchen staff and, implicitly, management).

27. In re Raymour \& Flannigan Furniture, No. GE-851-0306-ZAY, 2008 WL 2941771 , at $* 1$ (N.J. Admin. Apr. 21, 2008) (finding trucking company failed to pay overtime wages in violation of state and federal law and ordering an internal audit to determine how much back pay the company owes), aff d, 964 A.2d 830 (N.J. Super. Ct. App. Div. 2009); see also Erik Ortiz, Raymour \& Flanigan Drivers Get \$2M. for OT, $\begin{array}{lllll}\text { PRESSOFATLANTICCITY.COM (July } & 8, & 2009, & 3: 05 & \text { AM), }\end{array}$ http://www.pressofatlanticcity.com/business/article_394857c2-233c-517c-9dd2fcf148daac8c.html.

28. Chao v. Atlantic Auto Care Ctr., Inc., No. 1:05-cv-06786-BSJ (S.D.N.Y. Dec. 15,2009 ) (settling $\$ 3.6$ million between workers and car wash employer after employer failed to pay wages and overtime); Libby Nelson, Car Wash Chain to Pay $\$ 3.4$ Million in Back Wages, N.Y. TIMES (June 30, 2009, 4:38 PM), http://cityroom.blogs.nytimes.com/2009/06/30/car-wash-chain-will-pay-34-million-in-backwages.

29. Barfield v. N.Y.C. Health \& Hosps. Corp., 432 F. Supp. 2d 390, 392, 395 (S.D.N.Y. 2006) (granting summary judgment in favor of plaintiff, a traveler nurse, against defendant hospital and defendant temporary nurse agency where her employers failed to pay her overtime in sixteen different weeks that she worked over forty hours), aff' $d, 537$ F.3d 132, 153 (2d Cir. 2008).

30. Steven Greenhouse \& Stephanie Rosenbloom, Wal-Mart Settles 63 Lawsuits Over Wages, N.Y. TIMES (Dec. 23, 2008), http://www.nytimes.com/2008/12/24/busi ness/24walmart.html. 
ica's most celebrated chefs, owned (with others) three restaurants that stood accused of misappropriating the tips of servers and bartenders and failing to pay overtime. ${ }^{31}$ The FLSA collective action settled for $\$ 800,000$ after sixtyfive servers opted in to the lawsuit. ${ }^{32}$ In Los Angeles, the city attorney filed criminal charges against owners of four car washes, charging them with failure to pay the minimum wage and failure to provide the workers lawful breaks. ${ }^{33}$ In the subsequent lawsuit, workers claimed they were paid a flat rate of $\$ 35$ to $\$ 40$ dollars a day for shifts that lasted more than eight hours, and were given only fifteen minutes a day for lunch, while some workers alleged they worked for tips alone. ${ }^{34}$ These cases highlight some examples of wage and hour abuses that see the light of a courthouse, and with successful lawyering, compensate workers (though sometimes only partially) for lost wages.

But an increasing number of studies have shown that many low-wage workers continue to be subject to wage theft and often lack legal access to have their claims heard. The most comprehensive study of wage theft was published in 2009. ${ }^{35}$ A collaboration of non-profits and research centers conducted a survey of 4,387 workers in low-wage industries in the three largest U.S. cities: Chicago, Los Angeles, and New York. ${ }^{36}$ These "frontline" workers ${ }^{37}$ were employed by both large and small employers in a variety of industries, such as retail stores, residential construction, and home health care. ${ }^{38}$ The survey asked specific questions about their work and compensation in the previous work week..$^{39}$ Twenty-six percent of surveyed workers reported being paid less than minimum wage, with more than half underpaid by more than a dollar an hour. ${ }^{40}$ For the low-wage workers that worked over forty hours in a week, $76 \%$ faced unpaid or underpaid overtime. ${ }^{41}$ These (and other) violations resulted in a wage theft of $15 \%$ of earnings for the surveyed workers, and, if extrapolated to the nearly 1.12 million low-wage workers in the three cities, would result in low-wage workers losing more than $\$ 56$ million dollars per week. ${ }^{42}$

31. DeMunecas, 2010 WL 3322580 , at $* 1, * 3$.

32. Id. at *1.

33. Evelyn Larrubia, Criminal Charges Filed Against Car Wash Owners, L.A. TiMES (Feb. 10, 2009, 5:08 PM), http://latimesblogs.latimes.com/lanow/2009/02/los-angelescit.html.

34. Id.; BERNHARDT ET AL., supra note 7, at 1.

35. See BERNHARDT ET AL., supra note 7.

36. Id. at iii.

37. Id. at 2 (meaning exclusion of managers, professional, or technical workers).

38. Id. at 9 .

39. Id.

40. Id. at 2,20 .

41. Id.

42. Id. at 5-6. 
Smaller, more localized studies support the conclusion that low-wage workers suffer wage theft at an alarming rate. In New York City, 30\% of 436 retail workers interviewed reported that they worked over forty hours without being paid overtime, while $73 \%$ were not paid the four-hour minimum reporting pay when called in to work, as required by state law. ${ }^{43}$ In San Francisco, a survey of Chinatown workers reported that $50 \%$ of workers earned less than minimum wage, with $13 \%$ earning $\$ 5.00$ an hour or less. ${ }^{44}$ In Denver, Colorado, $40 \%$ of domestic workers surveyed earned less than minimum wage; $45 \%$ reported they were not paid for all hours worked; and $90 \%$ stated they worked sixty hours or more in a week yet failed to receive overtime pay. ${ }^{45}$

Reported litigation, combined with recent surveys, shows that wage theft is not uncommon or relegated to a few vulnerable industries by a handful of "rogue" employers. ${ }^{46}$ Instead, its widespread effects harm not only the poorest of our society, but also disadvantage responsible employers who are forced to compete with unscrupulous competitors in a tight labor market and slew economy. Some commentators blame the incentives to violate the FLSA for deepening the wage theft problem. ${ }^{47}$ When employers balance "'the expected costs of the mandated wage ... against the expected cost of non-compliance, ${ }^{\prime 48}$ given that the FLSA only allows for liquidated (double) damages with no punitive damage allowance, the calculus informs employers to keep their money in the bank and wait for enforcement, either private or public. Usually the wait is quite lengthy, if it comes at all, as the next section details.

\section{B. Under-Enforcement by Regulatory Agencies and the Barriers to Private Enforcement}

To vindicate their wage and hour statutory rights to recover lost wages owed to them, workers have few choices: file a complaint with the federal

43. Stephanie Luce \& NaOKI Fujita, Discounted Jobs: How Retallers Sell WORKERS SHORT 2, 8 (2012), available at http://retailactionproject.org/wpcontent/uploads/2012/01/Disconted-Jobs-FinalA.pdf.

44. Chinese Progressive Ass'N, Check, Please! Health and Working Conditions in SAN Francisco ChINATOWN RESTAuRANTS 4-5 (2010).

45. Tony Robinson, Jessie Dryden \& Heather Gomez-Duplantis, On the Job with Domestic Workers: Workplace Abuse and Worker Exploitation in Colorado's Invisible Workforce 15 (2010), available at http://www.centrohumanitario.org/Domestic\%20Worker $\% 20 \mathrm{El} \% 20$ Centro_Published.pdf.

46. Nat'L EmP't Law Project, Winning Wage Justice, supra note 21, at 6.

47. See Rogers, supra note 6, at 19-21.

48. Id. at 19 (quoting David Weil, Public Enforcement/Private Monitoring: Evaluating a New Approach to Regulating the Minimum Wage, 58 INDUS. \& LAB. REL. REv. 238, 239 (2005)). 
or state labor regulatory agency or bring a private cause of action under the FLSA or state wage and hour laws, or both. ${ }^{49}$

Federal government statistics reflect a decline in the number of workers served by the regulatory agency charged with enforcing our nation's wage and hours rights. An aggrieved employee can file a complaint to the Wage and Hour Division (WHD) of the U.S. Department of Labor (DOL). In 2008, the WHD received 23,845 complaints; such complaints have decreased in number each year since 2002. ${ }^{50}$ The WHD decides whether to conduct an investigation based on the information in the worker's complaint. ${ }^{51}$ If, during an investigation, the WHD determines that the employer violated the FLSA, it may seek FLSA enforcement by filing a civil suit. ${ }^{52}$ Advocates and many scholars agree that wage and hour enforcement has been hampered by a lack of resources and "political will to investigate lowwage workers' claims." 53

The most recent DOL statistics show that in 2008, the WHD concluded 28,242 cases and recovered roughly $\$ 185$ million dollars in backpay for 228,645 employees. ${ }^{54}$ This is the fewest number of resolved cases and fewest number of employees receiving recovery for lost wages since $2002 .{ }^{55}$ During this time period, one study found that the WHD suffered significant declines in staffing, with only 732 investigatory agents, the lowest number

49. See U.S. DEPT. LABOR, FairPay_Filing a Complaint for Back Wages Under the Fair Labor Standards Act (FLSA), http://www.dol.gov/whd/regs/compliance/fairpay/com plaint.htm (last visited Jan. 15, 2013); see, e.g., David Borgen \& Laura L. Ho, Litigation of Wage and Hour Collective Actions under the Fair Labor Standards Act, 7 EMP. RTS. \& EMP. POL'Y J. 129, 130 (2003) (describing "the development of the collective action as a means of private Fair Labor Standards Act enforcement and the issues that have arisen in implementing these procedures").

50. Wage \& Hour Div., U.S. Dep't of Labor, Wage and Hour Collects over \$1.4 Billion in Back Wages for over 2 Million Employees Since Fiscal Year 2001, at 1 (2008), available at $\mathrm{http}: / / \mathrm{www} . d o l . g o v / w h d /$ statistics/2008FiscalYear.pdf.

51. See 2 Les A. Schneider \& J. Larry Stine, Wage and Hour Law: Compliance \& PRACTICE $\S 19: 2$ (2004) (summarizing the criteria used by the Wage and Hour Division to select employers for investigation).

52. E.g., id. § 19:10 (outlining the WHD's options when it has found violations of the Act, which include taking no action, settling the matter with the employer, notifying the employees of their private right of action, referring the file for litigation, or closing the file after unsuccessful attempts at settlement).

53. Rita J. Verga, An Advocate's Toolkit: Using Criminal "Theft of Service" Laws to Enforce Workers' Right to Be Paid, 8 N.Y. CITY L. REv. 283, 286 (2005) (citing JENNIFER Gordon, CARNegie Endowment for InT'l PEACE, The Campaign for the UnPaid Wages Prohibition ACt: LATINo IMmigrants Change NeW YORK WAGE LAW 3-4 (1999), available at http://www.carnegieendowment.org/files/imp_wp4gordon.pdf); NAT'L EMP'T LAW ProjeCt, WinNING WAGE JUSTICE, supra note 21, at 6.

54. WAGE \& HOUR DIV., supra note 50, at 1.

55. See id. 
in thirty years. ${ }^{56}$ While at first blush, a decline in complaints to the DOL might be interpreted to mean a decreasing wage theft problem, this interpretation is at odds with recent studies of wage theft amongst the working poor and the concurrent increase in FLSA litigation filings. Instead, it reflects a deliberate choice of employees to vindicate wage rights through litigation and not government enforcement, a decision supported by the lack of enforcement resources.

The picture is grim for low-wage workers who wish to make a complaint to the DOL. In a report released in March 2009, the Government Accountability Office found that the WHD mishandled nine of the ten cases brought by a team of undercover agents posing as aggrieved workers. ${ }^{57}$ The report gives a stark example: a U.S. Government Accountability Office (GAO) undercover agent posing as a dishwasher called four times to complain about not being paid overtime for nineteen weeks; the DOL's Miami office failed to return his calls for four months, and when it did, an official told him it would take eight to ten months to begin investigating his case. ${ }^{58}$

Additionally, the DOL diminishes the deterrent effect it might have on dishonest employers when it publicizes the fact that it rarely seeks the full extent of damages afforded by the law and largely pursues individual monetary awards instead of seeking collective awards or industry-wide injunctive relief..$^{59}$ The investigators at the WHD are instructed not to include the liquidated damages amount in their negotiations with employers and to seek just two years of backpay, instead of the statutorily-allowed three, for willful violations. ${ }^{60}$

Since 2008, although DOL statistics are not yet available, one might predict that under the Obama Administration, the DOL's resources and policy agenda would increase enforcement. And some evidence supports that assumption: Obama promptly authorized 250 additional investigation

56. Irene Lurie, Enforcement of State Minimum Wage and Overtime Laws: Resources, Procedures, and Outcomes, 15 EMP. RTS. \& EMP. POL'Y J. 411, 412 (2011) (citing U.S. Gov'T ACCOUNTABILITY OfFICE, GAO-08-962T, FAIR LABOR STANDARDS ACT: BETTER Use of AVAILABLE RESOURCES AND CONSISTENT REPORTING COULD IMPROVE COMPLIANCE 6 (2008)) ("Only 732 investigators were on board in 2007 to enforce compliance with minimum wage and overtime laws across the country, fewer investigators than thirty years earlier.").

57. See U.S. Gov't ACCOUntability Office, GAO-09-458T, Department of LABOR: WaGe and Hour Division's COMPLAINT INTAKE AND INVESTIGATIVE PROCESSES Leave Low Wage Workers Vulnerable to WAGE THEFT 4 (2009), available at http://www.gao.gov/assets/130/122107.pdf; Steven Greenhouse, Labor Agency Is Failing Workers, Report Says, N.Y. TIMES, Mar. 25, 2009, at A16.

58. U.S. Gov'T ACCOUNTABILITY OFFICE, supra note 57, at 6.

59. See Nat'l Emp't LaW Project, Just Pay: Improving Wage and Hour ENFORCEMENT AT THE UNITED STATES DEPARTMENT OF LABOR 9-10 (2010), available at http://www.nelp.org/page/-/Justice/2010/JustPayReport2010.pdf?nocdn=1.

60. See id. at 10 . 
hires, ${ }^{61}$ the DOL implemented a new "regulatory philosophy" of requiring employers to audit themselves to ensure they are complying with the law, ${ }^{62}$ and the 2011 budget included $\$ 25$ million for the DOL to address the misclassification of employees, $\$ 12$ million of which was designated for enforcement of wage and overtime laws. ${ }^{63}$ Whether these measures can reverse a three-decade long decline in DOL enforcement remains to be seen.

Additionally, state wage and hour agencies are tasked with the enforcement of state wage and hour laws. States' efforts to enforce wage and hours laws vary greatly. ${ }^{64}$ One recent study found that " $[t]$ he resources that states devoted to enforcing their laws, the procedures they used, and the volume of their enforcement activity were strikingly different" and the "volume of enforcement activity ranged from 303 cases per thousand lowwage workers to four cases, and the wages collected per case ranged from $\$ 36,294$ to $\$ 128$." ${ }^{\prime s}$ Local studies of state agency enforcement support the conclusion that under-enforcement of state wage and hour laws remains common. Just over a decade ago, the New York State Department of Labor was challenged as systemically under-enforcing its wage and hour laws, as well as being unresponsive to immigrant workers' complaints. ${ }^{66}$ A 2002 study of California's Division of Labor Standards Enforcement found that its budget and staffing allocations have not kept up with growth of the state's workforce, and its investigations and penalties assessed have not increased in proportion to additional funding and staffing. ${ }^{67}$

The other avenue for workers to vindicate their statutory wage rights is to bring a private action in civil court without reporting the violation to the DOL. ${ }^{68}$ Of course, when an employee brings a civil claim to federal or state court, she is responsible for the costs of litigation, and in some juris-

61. Press Release, U.S. Dep't of Labor, Statement by Hilda L. Solis, U.S. Sec'y of Labor, on Wage and Hour Division's Increased Enforcement and Outreach Efforts (Nov. 19, 2009), available at http://www.dol.gov/opa/media/press/whd/whd20091452.htm.

62. Regulatory Agenda Narrative, U.S. DEP'T OF LAB. (2010), http://www.dol.gov/regulations/2010RegNarrative.htm.

63. Press Release, supra note 61; Seth D. Harris, DOL Deputy Secretary Seth D. Harris, U.S. DEPT. LABOR (JUNE 17, 2010), http://www.dol.gov/_sec/media/congress/ 20100617_Harris.htm.

64. Lurie, supra note 56 , at 433.

65. Id.

66. GoRDON, supra note 53, at 4-5.

67. Limor Bar-Cohen \& Deana Milam Carrillo, Labor Law Enforcement in California, 1970-2000, in STATE OF CALIFORNIA LABOR 135 (2002).

68. See 29 U.S.C. $\$ 216$ (b) (2006). Unlike Title VII of the Civil Right Act, where a plaintiff must first bring a charge of discrimination to the regulatory agency of the EEOC, a wage claim can be brought directly to court without first complaining to the regulatory agency. 
dictions, liable for attorneys' fees if she is not successful in the lawsuit. ${ }^{69}$ For low-wage workers this is a significant barrier to accessing the law. ${ }^{70}$ While free legal service organizations take some wage and hour cases, given how few there are and their small budgets, ${ }^{71}$ it remains a small drop in the bucket for addressing wage theft. Moreover, federally funded Legal Services Corporation offices are prohibited from representing undocumented workers, a significant number of the low-wage workers in America. ${ }^{72}$

Given the financial barriers to bringing individual private causes of action, aggregating low-wage workers' claims has been the primary source of private enforcement of wage theft.

\section{The Role of Class Actions In Protecting Against Wage Theft}

For low-wage workers who are unable to attain attorney representation for their individual wage theft claims, aggregating claims with other workers is often the only way to have their claims addressed. By combining their relatively small damage award with multiple similarly-situated workers, class action attorneys have an incentive to become "private attorney[s] general" in FLSA practice. ${ }^{73}$ As outlined below, there are advantages to low-

69. See, e.g., id. $\S 216$ (shifting fees to winning employees); Colo. REV. STAT. § 84-110 (2012) (shifting fees to the prevailing party in a wage dispute, either employer or employee); S.C. CODE ANN. $\S 41-10-80$ (2012) (shifting fees only to the employee in the event employee wins); OHı REv. CODE ANN. § 4111.10 (LexisNexis 2007) (shifting fees to employee if the employee wins); MISs. CODE ANN. § 71-3-59 (2012) (shifting fees to winning employers who defend against unreasonable claims).

70. See, e.g., Faisal Bhabha, Institutionalizing Access-to-Justice: Judicial, Legislative and Grassroots Dimensions, 33 QUEEN's L.J. 139, 141 (2007) ("[Access-to-justice initiatives] seek[] principally to address barriers to legal remedies created by the prohibitively high costs of litigation."); Marc Galanter, Access to Justice in a World of Expanding Social Capability, 37 FORDHAM URB. L.J. 115, 118 (2010) (citing the importance of access to justice initiatives as a means to combat cost barriers for low-income litigants); J. Maria Glover, The Structural Role of Private Enforcement Mechanisms in Public Law, 53 WM. \& MARY L. REV. $1137,1184-85$ (2012) (discussing the importance of fee-shifting provisions for low-income litigants in wage claims); Deborah L. Rhode, Access to Justice, 69 FORDHAM L. REV. 1785, 1804 (2001) (outlining the cost barriers that prevent low-income litigants from achieving justice).

71. See David Luban, Taking Out the Adversary: The Assault on Progressive Public-Interest Lawyers, 91 CALIF. L. REv. 209, 211-12 (2003) (noting the limited budgets of public assistance programs and the inability to take every case).

72. Omnibus Consolidated Rescissions and Appropriations Act of 1996, Pub. L. No. 104-134, $\S 504(a)(18), 110$ Stat. 1321-56 (1996). LSCs are also prohibited from litigating class actions, an important vehicle for vindicating wage theft, as seen in Part II of this Article.

73. James M. Fraser, Note, Opt-in Class Actions Under the FLSA, EPA, and ADEA: What Does It Mean to Be "Similarly Situated"?, 38 SUFFolK U. L. REV. 95, 99, 102-03 (2004); see also Newman v. Piggie Park Enters., 390 U.S. 400, 402 (1968) (per curiam); Holt 
wage workers in using this procedural device, and strong evidence suggests that individual wage and hour cases are becoming increasingly rare, while class and collective actions are growing. ${ }^{74}$

For minimum or overtime wage claims under the FLSA, ${ }^{75}$ statutory language in 29 U.S.C. $\S 216$ (b) trumps Federal Rule of Civil Procedure 23, meaning that wage "collective actions" 23 class actions. Rule 23 covers most types of cases, including consumer fraud, mass torts, antitrust, and civil rights. It operates as an opt-out device: if the class meets the rule's requirements, ${ }^{78}$ putative class members must "opt-out" in order to be removed from the reach of the case. ${ }^{79}$

v. Rite Aid Corp., 333 F. Supp. 2d 1265, 1269 (M.D. Ala. 2004) (citing Hoffmann-La Roche Inc. v. Sperling, 493 U.S. 165, $170(1989)$ ).

74. Вово, supra note 6, at 17, 19; see, e.g., Phelps v. 3PD, Inc., 261 F.R.D. 548, 563 (D. Or. 2009) (recognizing superiority of class actions in employment cases due to typically small size of individual awards); Chase v. AIMCO Props., L.P., 374 F. Supp. 2d 196, 198 (D.D.C. 2005) ("[I]ndividual wage and hour claims might be too small in dollar terms to support a litigation effort."); Sav-on Drug Stores, Inc. v. Superior Court, 96 P.3d 194, 209 (Cal. 2004) ("'[T] he class suit . . . provides small [overtime] claimants with a method of obtaining redress for claims which would otherwise be too small to warrant individual litigation." (quoting Richmond v. Dart Indus., Inc., 629 P.2d 23, 27 (Cal. 1981))); Noah A. Finkel, State Wage-and-Hour Law Class Actions: The Real Wave of "FLSA" Litigation?, 7 EMP. RTS. \& EMP. POL'Y J. 159, 162 n.9 (2003) (noting the success of class-actions in recent years, with settlements as high as $\$ 90$ million). See generally Glover, supra note 70 , at 1184 87 (highlighting the advantages of class actions in wage and hour claims); Catherine $\mathrm{K}$. Ruckelshaus, Labor's Wage War, 35 FORDHAM URB. L.J. 373, 385-86 (2008) (discussing factors that limit workers' access to the court system, including the small size of individual claims).

75. 29 U.S.C. § 201 (2006).

76. Early arguments that Rule 23 should apply to FLSA claims failed. See, e.g., Kinney Shoe Corp. v. Vorhes, 564 F.2d 859, 862 (9th Cir. 1977) ("The clear weight of authority holds that Rule 23 procedures are inappropriate for the prosecution of class actions under $\S 216($ b)."); Schmidt v. Fuller Brush Co., 527 F.2d 532, 536 \& n.4 (8th Cir. 1975) (noting that "Rule 23 cannot be invoked to circumvent [\$216(b)] consent" and "[courts] have uniformly ruled that .. Rule 23[ is] not applicable to ... § [2]16(b)"); LaChapelle v. Owens-Ill., Inc., 513 F.2d 286, 288, 289 (5th Cir. 1975) (finding "fundamental, irreconcilable difference between" Rule 23 and $\S 216(\mathrm{~b})$, and because $\S 216(\mathrm{~b})$ "is unambiguous," and "we must apply the law as it has been written").

77. Pub. L. No. 75-718, 52 Stat. 1060 (1938) (codified as amended at 29 U.S.C. § 201).

78. Rule 23(a) requires that:

(1) the class is so numerous that joinder of all members is impracticable;

(2) there are questions of law or fact common to the class;

(3) the claims or defenses of the representative parties are typical of the claims or defenses of the class; and

(4) the representative parties will fairly and adequately protect the interests of the class.

FED. R. CIV. P. 23(a). Additionally, a class also must qualify as one of the three Rule 23(b) types defined mainly by the relief sought. The least common, (b)(1), applies when separate actions risk multiple court orders inconsistent with each other or the rights of non-parties; 
In contrast, aggregate FLSA claims are governed by statutory rule: Section $216(\mathrm{~b}) .^{80}$ Pursuant to statute, these are "opt-in" actions, requiring each putative plaintiff to opt in to the suit by filing a consent-to-join form with the court in order to participate in the action. ${ }^{81} \mathrm{~A}$ brief historical overview is helpful to understand its importance and how this distinction evolved.

Enacted as part of the FLSA, and applicable to later employment laws codified in the same statutory chapter, Section 216(b) provides that "[a]n action ... may be maintained . . by any one or more employees for ... other employees similarly situated." ${ }^{82}$ Under the original statutory language, "collective action[s]" let employees designate third parties, mainly labor unions, to file their wage suits, but soon this practice drew heavy criticism. ${ }^{83}$ To eliminate third-party suits, in 1947 Congress amended Section 216(b) to require workers themselves be the plaintiffs ${ }^{84}$ and that other workers must affirmatively "opt in" by filing a written consent ${ }^{85}$ which reflected the prevailing class mechanism of the time ${ }^{86}$ This amendment came before modern Rule 23 opt-out classes were implemented to assist civil rights causes of action in the $1960 \mathrm{~s}$, and soon thereafter became the norm. ${ }^{87}$ The sole re-

Section (b)(2) applies when members seek mainly injunctive or declaratory relief against a party who acted on "grounds that apply generally to the class," as in lawsuits against segregation or pollution, while (b)(3) applies to money damages claims, making it most similar to $\S 216$ (b) wage collective actions. FED. R. CIV. P. 23(b). A (b)(3) class requires that common issues "predominate" over individual ones and that a class action be "superior to other" options, such as many individual suits. FED. R. CIV. P. 23(b)(3); see also Scott A. Moss \& Nantiya Ruan, The Second-Class Class Action: How Courts Thwart Wage Rights by Misapplying Class Action Rules, 61 AM. U. L. REv. 523, 530-32 (2012).

79. See FED. R. CIV. P. 23(c).

80. See 29 U.S.C. $\S \S 206-207,216$ (b) (2006).

81. See id. $\S 216(\mathrm{~b})$.

82. Id.

83. 93 CONG. REC. 2182 (1947) (remarks of Sen. Donnell) ("[C]ases in which an outsider, perhaps someone who is desirous of stirring up litigation without being an employee at all, . . . may result in very decidedly unwholesome champertous situations."); Moss \& Ruan, supra note 78, at 533 (citing Arrington v. Nat'l Broad. Co., 531 F. Supp. 498, 501 (D.D.C. 1982)).

84. Portal-to-Portal Act of 1947, Pub. L. No. 80-49, $§ 5(a), 61$ Stat. 84, 87 (1947) (codified as amended at 29 U.S.C. $\S 216(\mathrm{~b})$ ); see also Ruan, supra note 6, at 731-32 (referring to such claims as "blackmail" suits (citing Fraser, supra note 73, at 98)).

85. See Hoffmann-La Roche Inc. v. Sperling, 493 U.S. 165, 173 (1989) ("In enacting the Portal-to-Portal Act of $1947, \ldots$ the requirement that an employee file a written consent was added [to $\S 216(\mathrm{~b})$ ].").

86. On June 25, 1938, when the FLSA was enacted, the Federal Rules of Civil Procedure were pending before Congress and not yet effective, and modern Rule 23 class actions would not exist until 1966. See FED. R. ClV. P. 23 (1966 amend.).

87. See Nantiya Ruan, Bringing Sense to Incentives: An Examination of Incentive Payments to Named Plaintiffs in Employment Discrimination Class Actions, 10 EMP. RTS. \& EMP. POL'Y J. 395, 400-01 (2006). 
quirement of Section 216(b) is that members must be "similarly situated" and opt into the action individually.

The procedural oddity that is Section 216(b), combined with the value of most individual wage theft claims, sets the stage for an increased role that aggregate litigation plays for low-wage workers. ${ }^{88}$

\section{A. The Difficulties in Prosecuting Small Wage Claims}

The courts, including the U.S. Supreme Court, routinely recognize the importance of aggregate litigation because it often remains the only means of judicial relief where a plaintiff's claim is too small economically to support individual litigation. ${ }^{89}$ Where the value of the claim is less than the transaction costs, such "negative-value" claims typically are heard only if brought in the aggregate..$^{90}$ Most claims of low-wage workers involve relatively small per-person damages, ${ }^{91}$ and although these lost wages are crucial

88. Much of the research and ideas expressed in these next subsections were articulated by the author in a previously co-authored piece written for the amicus brief on behalf of the Lawyers' Committee for Civil Rights Under the Law et al., in support of the respondents in the $A T \& T$ Mobility LLC v. Concepcion case before the Supreme Court in 2010. See Brief for Lawyers' Committee for Civil Rights Under Law et al. as Amici Curiae Supporting Respondents, AT\&T Mobility LLC v. Concepcion, 2010 WL 3935515 (9th Cir. Oct. 6, 2010) (No. 09-893).

89. See Amchem Prods., Inc. v. Windsor, 521 U.S. 591, 617 (1997) (noting that the policy at the very core of the class action mechanism " is to overcome the problem that small recoveries do not provide the incentive for any individual to bring a solo action prosecuting his or her rights"' (quoting Mace v. Van Ru Credit Corp., 109 F.3d 338, 344 (7th Cir. 1997))); Phillips Petroleum Co. v. Shutts, 472 U.S. 797, 809 (1985) ("Class actions . . permit the plaintiffs to pool claims which would be uneconomical to litigate individually."); Deposit Guar. Nat'l Bank of Jackson, Miss. v. Roper, 445 U.S. 326, 339 (1980) ("Where it is not economically feasible to obtain relief within the traditional framework of a multiplicity of small individual suits for damages, aggrieved persons may be without any effective redress unless they may employ the class-action device.").

90. Chen-Oster v. Goldman, Sachs \& Co., No. 10 Civ. 6950(LBS)(JCF), 2011 WL 2671813 , at $* 4$ (S.D.N.Y. July 7, 2011) ("In this case, the plaintiff would be foreclosed from bringing her pattern or practice claim . . by the practicality of economic pressures limiting the value of her claim compared with the cost of prosecuting it . ..."); Mascol v. E \& L Transp., Inc., No. CV-03-3343 CPS, 2005 WL 1541045, at *7 (E.D.N.Y. June 29, 2005) (holding "the class action form is superior to alternative methods of adjudicating this controversy" because the claims were negative value); Iliadis v. Wal-Mart Stores, Inc., 922 A.2d 710,725 (N.J. 2007) ("Because of the very real likelihood that class members will not bring individual actions, class actions are 'often the superior form of adjudication when the claims of the individual class members are small.'" (quoting Weber v. Goodman, 9 F. Supp. 2d 163, 170-71 (E.D.N.Y. 1998))).

91. See Phelps v. 3PD, Inc., 261 F.R.D. 548, 563 (D. Or. 2009) (recognizing the superiority of class actions due to the typically small size of individual awards); Chase v. AIMCO Props., L.P., 374 F. Supp. 2d 196, 198 (D.D.C. 2005) ("[I]ndividual wage and hour claims might be too small in dollar terms to support a litigation effort."); Sav-on Drug Stores, Inc. v. Superior Court, 96 P.3d 194, 209 (Cal. 2004) (observing, in an overtime action, that 
to the workers themselves, they fail to capture the attention of a plaintiff's attorney who, although entitled to statutory fees under the FLSA, ${ }^{92}$ can only justify the resources it takes to successfully prosecute wage claims if they involve multiple plaintiffs. ${ }^{93}$

Additionally, individual litigation requires one plaintiff to shoulder the demands of the lawsuit, including spending many hours assisting in the investigation of the claims and bearing the costs (both financial and personal) of the litigation. Most low-wage workers working on an hourly basis simply cannot afford the time and expense it would take to prosecute the claims individually, nor can they proceed on their own, even if they could navigate the DOL regulatory complaint process or litigate the claims successfully in court pro se. When proceeding as a collective action, the extent to which any one worker bears the burden of prosecuting the litigation is limited.

\section{B. The Threat of Retaliation}

Across industries and where unemployment rates are high, the threat of reprisal for bringing a legal claim against one's employer prevents many workers from pursuing litigation. ${ }^{94}$ Current employees fear termination, retaliation in the form of change in schedule or job duties, harassment, or

\footnotetext{
“"the class suit ... provides small claimants with a method of obtaining redress for claims which would otherwise be too small to warrant individual litigation" (quoting Richmond v. Dart Indus., Inc., 629 P.2d 23, 27 (Cal. 1981))); Ruckelshaus, supra note 74, at 386 (discussing factors, including the typically small size of each individual worker's claim, that contribute to workers' lack of access to the courts); U.S. Gov'T ACCOUNTABILITY OFFICE, supra note 57, at 9 ("Low wage workers may be unable to afford attorney's fees or may be unwilling to argue their own case in small claims court, leaving them with no other options to obtain their back wages.").

92. 29 U.S.C. $§ 216(2006)$.

93. See Scott v. Aetna Servs., Inc., 210 F.R.D. 261, 268 (D. Conn. 2002) (concluding that a class action is the superior method for bringing plaintiffs' overtime claims, in part, because "the cost of individual litigation is prohibitive"); Ansoumana v. Gristede's Operating Corp., 201 F.R.D. 81, 85-86 (S.D.N.Y. 2001) (noting that individual suits, as an alternative to class litigation, may not be feasible based on class members' lack of financial resources and disincentives for attorneys).

94. See Andrew C. Brunsden, Hybrid Class Actions, Dual Certification, and Wage Law Enforcement in the Federal Courts, 29 BERKELEY J. EMP. \& LAB. L. 269, 296-97 (2008) ("Workers do not pursue rights claims in a vacuum; there are risks to participating in rights enforcement because one must decide whether to challenge employer practices from within the employment relationship."); David Weil \& Amanda Pyles, Why Complain? Complaints, Compliance, and the Problem of Enforcement in the U.S. Workplace, 27 COMP. LAB. L. \& POL'Y J. 59, 83 (2005) (referring to studies suggesting that "despite explicit retaliation protections under various labor laws, being fired is widely perceived to be a consequence of exercising certain workplace rights"); Steven G. Zieff, Advanced Issues in Collective Actions, 10 EMP. RTS. \& EMP. POL'Y J. 435, 437 (2006).
} 
reduction in pay. ${ }^{95}$ As the authors of the most comprehensive wage theft study found, $43 \%$ of the low-wage workers surveyed who complained about violations of workplace standards were retaliated against, including being fired, suspended, or threatened with reductions in hours or pay ${ }^{96}$ For former workers who fear difficulties in finding new employment opportunities, being part of a federal litigation is too threatening to contemplate. Workers fear industry "blacklisting" and lack of positive job references, a necessary ingredient for successful job hunts. ${ }^{97}$

The Supreme Court has recognized the imbalance of power that engenders such fear in workers. As Justice Marshall acknowledged in a Supreme Court decision of 1978, employers, "by virtue of the employment relationship, may exercise intense leverage. Not only can the employer fire the employee, but job assignments can be switched, hours can be adjusted, wage and salary increases held up, and other more subtle forms of influence exerted." 98

For low-wage workers, these concerns are especially poignant given their precarious job security. Low-wage workers are particularly vulnerable to retaliation because many live "paycheck to paycheck" in mostly lowskilled jobs, where employers consider them replaceable and therefore expendable. ${ }^{99}$ Low-wage workers are therefore loath to challenge unlawful wage practices, especially when unemployment rates are high. For immigrant workers with limited English proficiency and little familiarity with their legal rights, challenging wage theft is nearly impossible. ${ }^{100}$

95. See, e.g., Mitchell v. Robert DeMario Jewelry, Inc., 361 U.S. 288, 289-90 (1960) (noting that plaintiffs were fired after they filed FLSA claims based on employer's "displeasure" over their actions); Brock v. Casey Truck Sales, Inc., 839 F.2d 872, 874 (2d Cir. 1988) (noting that employees were discharged after refusing to take a "loyalty oath" repudiating their rights to unpaid wages); Steven Greenhouse, Forced to Work Off the Clock, Some Fight Back, N.Y. TIMES, Nov. 19, 2004, at A1 (quoting a former manager stating that workers who complained of wage and hour violations were "'weeded out and terminated").

96. BERNHARDT ET AL., supra note 7, at 3 .

97. See, e.g., Mori-Noriega v. Antonio's Rest., Inc., 923 F.2d 839, 839 (1st Cir. 1990) (unpublished table decision) (noting that plaintiff's current employer fired him because he had cooperated with the Department of Labor in its investigation of his former employer's violation of wage and hour laws).

98. NLRB v. Robbins Tire \& Rubber Co., 437 U.S. 214, 240 (1978).

99. See BoBo, supra note 6, at 7-15; BERnhARDT ET AL., supra note 7, at 9 ("Although women, immigrants, and people of color are disproportionately affected by workplace violations, we found that where a worker is employed -that is, in which industry and in what type of job - is generally a much better predictor of violations than the worker's demographic characteristics.").

100. See BERnhardt et AL., supra note 7, at 5 (citing increased proficiency in English as one way to combat wage theft); id. at 42 (noting the increased likelihood of a wage violation for workers with limited English proficiency). See generally GARCIA, supra note 21. 
However, collective actions under the FLSA protect workers from retaliation to a lesser extent than Rule 23 class actions. Rule 23(d) provides a mechanism for judges to enter orders protecting the class, such as authorizing certain discovery and banning harassing litigation tactics. ${ }^{101}$ Additionally, class actions under Rule 23 help alleviate plaintiffs' fear of retaliation because they allow all but a few named plaintiffs to pursue their rights without having to opt in to the suit. They are "nameless" and "faceless" in the litigation until liability is found and damages are assessed. ${ }^{102}$ In contrast, for FLSA collective actions, each worker must affirmatively opt in to the suit, which puts their name before both the court and the employer's attorneys in the early stages of the litigation. ${ }^{103}$ Although no study yet has determined that FLSA plaintiffs face a greater rate of retaliation than Rule 23 plaintiffs, the perception of workers is that they are more exposed by affirmatively opting in, and that perception works to dissuade workers from participating.

\section{The Importance of Notification Under 216(b)}

Today, many workers, especially low-wage workers, are unaware that their statutory wage rights have been violated until they are specifically informed of the violation. Unlike the Civil Rights Movement of the 1960s, where the societal ideal of anti-discrimination was discussed openly and publicly, wage protection laws enjoyed their heyday (if at all) close to eighty years ago, when the New Deal legislation addressed the abysmal conditions of the working poor. ${ }^{104}$ Some employers misinform (either intentionally or unintentionally) their employees that the law does not protect them or that they are exempt from minimum wage or overtime laws. ${ }^{105}$ For

101. Fed. R. CIV. P. 23(d); see also Guifu Li v. A Perfect Day Franchise, Inc., 270 F.R.D. 509 (N.D. Cal. 2010).

102. Moss \& Ruan, supra note 78, at 533-34 (discussing the relative advantages of being an unnamed plaintiff in a class action).

103. 29 U.S.C. 216(b); see also Hoffmann-La Roche, Inc. v. Sperling, 493 U.S. 165, 173 (1989) (noting that the 1947 Portal-to-Portal Act added a "requirement that an employee file a written consent").

104. Congress passed the Fair Labor Standards Act (FLSA) in 1938 to combat "the existence . . . of labor conditions detrimental to the maintenance of the minimum standard of living necessary for health, efficiency, and general well-being of workers." 29 U.S.C. $\S$ 202(a) (2006).

105. Misra v. Decision One Mortg. Co., 673 F. Supp. 2d 987, 991 (C.D. Cal. 2008) (indicating that defendants misrepresented to employees that they were exempt and not entitled to overtime pay); Kamens v. Summit Stainless, Inc., 586 F. Supp. 324, 328 (E.D. Pa. 1984) (noting that plaintiffs alleged affirmative misrepresentations by employer which were sufficient to toll the statute of limitations applicable to their claims); Gentry v. Superior Court, 165 P.3d 556, 567 ("The likelihood of employee unawareness is even greater when, as alleged in the present ease, the employer does not simply fail to pay overtime but affirmatively tells its employees that they are not eligible for overtime."). 
immigrants, Hoffman Plastics Compounds (which limited backpay remedies to undocumented workers in a NLRA suit) likely has contributed to the confusion on whether they can prosecute their wage rights in a court of law. ${ }^{106}$

Courts have reasoned that notice to affected workers who must affirmatively opt in to the suit before the statute of limitations runs out ${ }^{107}$ is a necessary component of collective action procedure. ${ }^{108}$ Early in the litigation, notice of collective action pursuant to Section 216(b) provides workers not only information regarding their wage rights, but an entry point into the legal system by directing them to the plaintiffs' attorneys for counsel. By letting workers know of an ongoing litigation, they can gain some measure of security and comfort knowing that they are not alone in challenging the policies and practices of their employers.

\section{Deterring Future Wage Theft}

Through aggregating claims, workers benefit from the increased pressure employers feel when faced with collective litigation and the opportunities for making positive, systemic changes in the workplace through classwide discovery and injunctive relief.

Collective actions provide a strong counterbalance to employers' incentive to violate the FLSA. The sheer magnitude and scope of class litigation enhances the likelihood that a targeted employer will comply with the law. In fact, plaintiffs' attorneys note that upon service of a class complaint, workers report that the employer changes its wage practices to come into compliance with the law. ${ }^{109}$ The ability of collective claims to obtain significant damages in back pay and potential attorneys' fees (even absent punitive damages) changes the calculus for employers contemplating compliance or noncompliance.

106. Keith Cunningham-Parmeter, Fear of Discovery: Immigrant Workers and the Fifth Amendment, 41 CORNELl INT'L L.J. 27, 28 (2008); Ruben J. Garcia, Ten Years After Hoffman Plastic Compounds, Inc. v. NLRB: The Power of a Labor Law Symbol, 21 CORNELL J.L. \& PUB. POL'Y 659, 669 (2012) (noting that while "[t]he true impact of Hoffman may be hard to determine," nevertheless "courts have generally not extended Hoffman past the issue of back pay under the [National Labor Relations Act], but the breadth of the Court's holding can be applied to remedies other than back pay").

107. 29 U.S.C. § 255(a) (2006); see also Brock v. Richland Shoe Co., 799 F.2d 80 (3d Cir. 1986) (finding a willful violation after company vice president and general manger admitted to knowing the FLSA applied to overtime pay).

108. See, e.g., Sipas v. Sammy's Fishbox, Inc., No. 05 Civ. 10319(PAC), 2006 WL 1084556, at *1 (S.D.N.Y. Apr. 24, 2006).

109. Interview with Adam T. Klein, Partner, Outten \& Golden LLP, in N.Y.C., N.Y. (Oct. 26, 2011) (on file with author). 
Moreover, collective actions under the FLSA brought by the DOL can include injunctive relief as a remedy. ${ }^{110}$ Injunctive relief-mandating changes in corporate policies and practices--can have a tremendous impact on low-wage workers, especially when involving large employers."' While some scholars have criticized employment discrimination class actions as having little to no effect on actual positive change in the workplace because of the lack of meaningful injunctive relief, ${ }^{112}$ such criticism has not yet targeted FLSA collective actions, perhaps because DOL actions are relatively rare, or perhaps because wage violations (denying overtime, classifying too many as "exempt," etc.) are easier to stop than more decentralized, more subjective hiring decisions that may be based on subconscious or at least hidden discriminatory intent.

Lastly, when alleging wage and hour violations, the same corporate policies, patterns, and practices usually affect multiple workers in a workplace, not just individuals. When litigating an individual suit, it can be difficult to identify and prove systemic violations, in part because companywide discovery is not allowed or affordable. ${ }^{113}$ In contrast, collective actions demand that plaintiffs prove that employees are "similarly situated," which opens the door to the discovery of class-wide statistics and evidence.

However, while these pressures legitimately promote compliance with wage laws by unscrupulous employers, the same procedures are said to ap-

110. See, e.g., Powell v. Florida, 132 F.3d 677, 678 (1 l th Cir. 1998); Vega Castro v. Puerto Rico, 43 F. Supp. 2d 186, 191 (D.P.R. 1999), aff'd sub nom. Jusino Mercado v. Puerto Rico, 214 F.3d 34 (1 st Cir. 2000); EEOC v. AT\&T Co., 365 F. Supp. 1105, 1121 (E.D. Pa. 1973), aff d, 506 F.2d 735 (3d Cir. 1974).

111. See, e.g., Butler v. Home Depot, Inc., Nos. C-94-4335 SI, C-95-2182 SI, 1997 WL 605754 (N.D. Cal. Aug. 29 1997) (doubling the representation of women in management-track positions at Home Depot, one of the nation's largest retail chains); Freeman v. City of Philadelphia, 751 F. Supp. 509, 513-14, 522 (E.D. Pa. 1990) (increasing the number of African-American police officers in Philadelphia's police force from $12 \%$ to $35 \%$ ); Pub. Interest Law Ctr. of Phila., Law Center Joins Forces with Other Civil Rights Organizations to Protect Ability to Combat Discrimination with Class Action Lawsuits (Oct. 31, 2007) (noting the increase in the number of African-Americans in Philadelphia's police force as a result of the consent decree); Home Depot, Female Employees Report Progress, HR.BLR.COM (June 24, 2002), http:/hr.blr.com/HR-news/Discrimination/SexDiscrimination/Home-Depot-Female-Employees-Report-Progress (reporting the increase in the number of women in management-track jobs at Home Depot).

112. See, e.g., Michael Selmi, The Price of Discrimination: The Nature of Class Action Employment Discrimination Litigation and Its Effects, 81 TEX. L. REV. 1249, 1249-50 (2003).

113. See Rebecca Love Kourlis \& Dirk Olin, Rebuilding Justice: Civil Courts IN JEOPARDY AND WHY YOU SHOULD CARE (2011) (noting the high cost of discovery in civil litigation and its hindering effects on achieving justice); Emery G. Lee III \& Thomas E. Willging, Defining the Problem of Cost in Federal Civil Litigation, 60 DuKE L.J. 765, 769$70(2010)$ (reporting that a survey of federal cases in 2008 showed "median litigation costs, including attorneys' fees, of $\$ 15,000$ for plaintiffs and $\$ 20,000$ for defendants" "[i]n cases in which one or more types of discovery was reported"). 
ply unfair pressure on employers who sought to pay their workers lawfully but are faced with collective litigation on wage practices that might or might not be considered in violation of the FLSA. ${ }^{14}$ These arguments point to the "gun to the head" settlement pressure that class actions have on employers; many commentators have expressed concern over class litigation because of this pressure, and many have called for a congressional response, to which there has been some success. ${ }^{115}$

These concerns are lessened, but perhaps not wholly alleviated by, the 216(b) procedural mechanism. As opposed to the unnamed plaintiffs of Rule 23 classes, FLSA collective actions are comprised only of workers that affirmatively opt in and report wage violations similar to those the named plaintiffs allege. Because of this procedural quirk, employers are faced with fewer collective plaintiffs and, therefore, lower costs. Also, in contrast to the complex burden shifting standards of Title VII or intricacies of anti-trust law, ${ }^{116}$ the liability standard under the FLSA is relatively straightforward, which supports a healthy skepticism of whether employers facing FLSA actions are truly unknowing victims of "gotcha" litigations."17

114. Glover, supra note 70 , at 1196 ("[U]nder the American rule of litigationwhereby each party bears his own litigation costs-virtually all of the costs in these cases will be borne by defendants, who likely have little to request in the way of discovery from plaintiffs. As a result, discovery alone can generate significant settlement pressure even if the defendants did nothing wrong and are likely to be ultimately exonerated." (footnote omitted)).

115. The Class Action Faimess Act of 2005 (CAFA), Pub. L. No. 109-2, 119 Stat. 4, substantially changed the landscape of class action procedure in federal courts. 28 U.S.C. $\S$ 1332(d) (2006). Concerned with forum-shopping, unscrupulous class action attorneys, and professional plaintiffs, the Act codified a "consumer class action bill of rights" and expanded federal diversity jurisdiction for class claims. 119 Stat. at 5 . However, even within the CAFA debate, Congress recognized the value class actions have for small claims: "Class actions were designed to provide a mechanism by which persons, whose injuries are not large enough to make pursuing their individual claims in the court system cost efficient, are able to bind together with persons suffering the same harm and seek redress for their injuries." $\mathrm{S}$. REP. No. 109-14, at 4 (2005). Then-President Bush agreed:

Class-actions can serve a valuable purpose in our legal system. They allow numerous victims of the same wrongdoing to merge their claims into a single lawsuit. When used properly, class-actions make the legal system more efficient and help guarantee that injured people receive proper compensation. That is an important principle of justice.

Press Release, Office of the Press Sec'y, President Signs Class-Action Fairness Act of 2005, (Feb. 21, 2005), available at http://georgewbush-whitehouse.archives.gov/news/releases /2005/02/20050218-11.html.

116. See, e.g., Peter M. Gilhuly \& Ted A. Dillman, Officers' and Directors' Personal Liability for Wages: The Impact and Limits of Boucher v. Shaw, 29 AM. BANKR. INST. J. 56, 56 (2010) (comparing the stricter liability standards of the Federal Worker Adjustment Retraining and Notification Act to the more liberal FLSA standards).

117. See, e.g., In re Rhone-Poulenc Rorer Inc., 51 F.3d 1293, 1298 (7th Cir. 1995) ("Judge Friendly, who was not given to hyperbole, called settlements induced by a small probability of an immense judgment in a class action "blackmail settlements." (quoting 


\section{ThE GROWTH OF MANDATORY ARBITRATION AND ClasS WAIVERS IN EMPLOYMENT CONTEXTS}

As the number of wage and hour suits precipitously rose in the last decade, a parallel trend of arbitration as the "new litigation" 118 gained momentum. The growing number of arbitration clauses in contracts of all sorts-trade, consumer, and most importantly for this Article, employment-resulted in private arbitration becoming a "parallel judicial system," 119 one that allows employers with superior bargaining power to define the parameters of the dispute resolution process.

For employees, mandates to arbitrate any and all conflicts resulting from their employment can be found in a variety of places: an offer letter or job application, ${ }^{120}$ a slip of paper in the envelope that holds their paycheck, ${ }^{121}$ the employer's employment handbook, ${ }^{122}$ or a severance agreement. ${ }^{123}$ In whichever form they take, arbitration clauses are estimated to cover at least 30 million employees, ${ }^{124}$ a number that most commentators agree is sure to continue rising ${ }^{125}$ given the broad support they have received

Henry J. Friendly, Federal Jurisdiction: A General View 120 (1973))); Robert R. Niccolini, McGuireWoods LLP, Recent Developments in Labor and Employment Law, Seminar Before the American Health Lawyers Association (Feb. 23, 2005) (" $[N]$ ew regulations [in the Department of Labor] also expand the exceptions from impermissible salary deductions, narrow employers' potential liabilities if improper deductions are made to otherwise exempt employees, salaries, and allow employers a safe harbor to reduce employers' liability from gotcha claims." (discussing 29 C.F.R. $\$ 541.603$ (2005))). See generally Dan Downey \& Lori Massey, Discoverectomy II: The End of "Gotcha" Litigation, 13 REV. LITIG. 183 (1994); Dan Downey, Discoverectomy: A Proposal to Eliminate Discovery, 11 REV. LITIG. 475 (1992) (describing a plan to reduce gotcha litigation and streamline discovery). 1,8 .

118. Thomas J. Stipanowich, Arbitration: The "New Litigation," 2010 U. ILL. L. REV.

119. David Horton, Arbitration as Delegation, 86 N.Y.U. L. ReV. 437, 439 (2011) (citing Stipanowich, supra note 118, at 8).

120. Gilmer v. Interstate/Johnson Lane Corp., 500 U.S. 20, 20 (1991) (requiring plaintiff to register as a securities representative with the New York Stock Exchange as a condition of his employment, which contained an arbitration agreement); Lewis v. Labor Ready Mid-Atl., Inc., No. 3:08-1085, 2009 WL 497692, at *5 (M.D. Tenn. Feb. 26, 2009).

121. Tinder v. Pinkerton Sec., 305 F.3d 728, 731 (7th Cir. 2002).

122. Martin v. Citibank, Inc., 567 F. Supp. 2d 36, 42 (D.D.C. 2008).

123. In re Pac. Gas \& Electric Co., No. CV-08-1211 CW, 2008 WL 2004275, at *1 (N.D. Cal. May 5, 2008).

124. Martha Halvordson, Employment Arbitration: A Closer Look, 64 J. Mo. B. 174, 174 (2008).

125. Alexander J.S. Colvin, Empirical Research on Employment Arbitration: Clarity Amidst the Sound and Fury?, 11 EMP. RTS. \& EMP. POL'Y J. 405, 411 (2007); Kathleen L. Daerr-Bannon, Cause of Action to Enforce Arbitration in Employment Disputes, in 15 CAUSES OF ACTION 2D 215, 220 (2000); Horton, supra note 119, at 439 ("Arbitration clauses appear in hundreds of millions of consumer and employment contracts."); Bryon Allyn Rice, Comment, Enforceable or Not?: Class Action Waivers in Mandatory Arbitration Clauses and the Need for a Judicial Standard, 45 Hous. L. REV. 215, 220-22 (2008); John B. Wright 
from the judiciary, especially the U.S. Supreme Court. As Justice O'Connor noted in 1995, in structuring arbitration as a preferred forum for dispute resolution, the Supreme Court has been "building ... case by case, an edifice of its own creation." 126

The latest stamp of approval came in April 2010, when the Supreme Court held in $A T \& T$ Mobility $L L C$ v. Concepcion that corporate boilerplate language in AT\&T's consumer contract mandating individual dispute resolution (with no opportunity to aggregate claims in class actions, known colloquially as the "class waiver") is enforceable and consistent with federal public policy. ${ }^{127}$ The combined effect of mandatory arbitration and class waivers facilitates the silencing of low-wage workers from voicing wage theft claims. Shedding light on how arbitration works reveals its impact in the employment context.

\section{A. Judicial Enforcement: The FAA}

In 1925, Congress passed the Federal Arbitration Act (FAA) to support the private resolution of breach of contract disputes between trade merchants. ${ }^{128}$ Persuaded by the American Bar Association (ABA) and various business groups that hostility to arbitration hindered trade, ${ }^{129}$ Congress enacted the FAA to counteract the " "jealous notion ... that arbitration agreements were nothing less than a drain on [the courts'] own authority to settle

et al., Arbitration Trends and Limitations-Class Action Arbitration, in 3 SUCCESSFUL PARTNERING BeTWEen INSIDE AND OUTSIDE COUNSEL $§ 57: 53$ ("As the Supreme Court has expanded the scope of the FAA and fostered pro-arbitration jurisprudence, arbitration clauses have become a routine part of standard form contracts, not only for sophisticated commercial transactions like the one in Stolt-Nielsen, but also for consumer, franchise and employment contracts." (emphasis added)); Contract Administration, in 2 POLICIES AND PRACTICES $\S$ 152:15 (2013) ("Most labor agreements contain provisions for binding arbitration of unresolved grievances.").

126. Allied-Bruce Terminix Cos. v. Dobson, 513 U.S. 265, 283 (1995) (O’Connor, J., concurring).

127. AT\&T Mobility LLC v. Concepcion, 131 S. Ct. 1740, 1747-53 (2011) (interpreting the United States Arbitration Act, known as the Federal Arbitration Act, Pub. L. No. 68401, 43 Stat. 883 (1925) (codified as amended at 9 U.S.C. $\S \S 1-16(2006))$ )).

128. Horton, supra note 119 , at $444 \mathrm{n} .32$ ("“'The FAA] is a remedy peculiarly suited to the disposition of the ordinary disputes between merchants as to questions of factquantity, quality, time of delivery, compliance with terms of payment, excuses for nonperformance, and the like." (alteration in original) (quoting Julius Henry Cohen \& Kenneth Dayton, The New Federal Arbitration Law, 12 VA. L. REV. 265, 281 (1926))).

129. Pub. L. No. $68-401,43$ Stat. 883 (1925) (codified as amended at 9 U.S.C. $\S \S 1-$ 16 (2006)); see also IAN R. MACNEIL, AMERICAN ARBITRATION LAW: REFORMATIONNATIONALIZATION-INTERNATIONALIZATION 84-91 (1992) (describing how American Bar Association officials and businessmen successfully lobbied for FAA's enactment). 
disputes." ${ }^{\prime 30}$ As a multitude of courts have since recognized, Congress intended to place arbitration agreements on "equal footing with other contracts" and establish a "strong federal policy favoring arbitration." 131

Section 2 of the FAA provides, quite simply, that "[a] written provision in any maritime transaction or a contract evidencing a transaction involving commerce to settle by arbitration a controversy thereafter arising out of such contract or transaction . . . shall be valid, irrevocable, and enforceable." 132 The broad policy in favor of arbitration is tempered within the language of the FAA itself in $\S 2$, where the "savings clause" allows for any party to oppose arbitration on grounds that "exist at law or in equity for the revocation of any contract." 133

Additionally, $\S 1$ offers an express statutory exception for certain employment contracts, namely "seamen, railroad employees, or any other class of workers engaged in foreign or interstate commerce." 134 Section 4 of the FAA provides that "[a] party aggrieved by the alleged failure, neglect, or refusal of another to arbitrate under a written agreement for arbitration may petition any United States district court . . . for an order directing that such arbitration proceed in the manner provided for in such agreement." 135 If a litigant in a court proceeding refuses to arbitrate a dispute within the scope of a valid arbitration agreement, a judicial order compelling arbitration is mandatory, not discretionary. ${ }^{136}$

The long and somewhat tortured path of the FAA from a policy promoting the efficient settlement of conflicts between merchants pursuant to industry norms to "an invitation to the business community to create a parallel procedural regime" 137 is one that is largely outside the scope of this Article. ${ }^{138}$ However, as it relates to the increased relevance to employment relationships and, in particular, low-wage workers, an important starting

130. Cooper v. MRM Inv. Co., 367 F.3d 493, 498 (6th Cir. 2004) (quoting Raasch v. NCR Corp., 254 F. Supp. 2d 847, 853 (S.D. Ohio 2003)).

131. See Concepcion, 131 S. Ct. at 1745; Perry v. Thomas, 482 U.S. 483, 489 (1987); JLM Indus., Inc. v. Stolt-Nielsen SA, 387 F.3d 163, 171 (2d Cir. 2004) (quoting Hartford Accident \& Indemn. Co. v. Swiss Reinsurance Am. Corp., 246 F.3d 219, 226 (2d Cir. 2001)).

132. 9 U.S.C. $\S 2(2006)$.

133. Id.

134. Id. $\S 1$.

135. Id. $\S 4$.

136. Id.

137. Horton, supra note 119 , at 444.

138. For a comprehensive overview of the historical development of the FAA as it relates to the modern judicial interpretation, see Matthew W. Finkin, "Workers' Contracts" Under the United States Arbitration Act: An Essay in Historical Clarification, 17 BERKELEY J. EMP. \& LAB. L. 282 (1996); Horton, supra note 119; and Judith Resnik, Comment, Fairness in Numbers: A Comment on AT\&T v. Concepcion, Wal-Mart v. Dukes, and Turner v. Rogers, 125 HARV. L. REV. 78 (2011). 
point is the Supreme Court's 1991 decision in Gilmer v. Interstate/Johnson Lane Corp. ${ }^{139}$

In Gilmer, a stockbroker's employer required him to register as a securities representative with the New York Stock Exchange. ${ }^{140}$ That application included an arbitration clause to arbitrate any dispute arising out of his employment. ${ }^{141}$ After the employee was terminated, he sued under the Age Discrimination in Employment Act (ADEA), alleging that he was fired unlawfully because of his age. ${ }^{142}$ The Supreme Court held that employers could require employees to agree, as a condition of employment, to arbitrate federal statutory age discrimination cases, with reasoning that spawned later case law holding that predispute arbitration clauses covering virtually any federal and state statutory claim were also enforceable. ${ }^{143}$ The Supreme Court stated clearly that " $[\mathrm{b}] \mathrm{y}$ agreeing to arbitrate a statutory claim, a party does not forgo the substantive rights afforded by the statute; it only submits to their resolution in an arbitral, rather than a judicial, forum."'/44

The Gilmer decision came as a surprise to some scholars ${ }^{145}$ and employee advocates given that a previous Supreme Court precedent seemingly squarely on point held that an employee could proceed to court on a statutory rights claim (Title VII) despite an arbitration agreement between the employer and the union. ${ }^{146}$ Nonetheless, Gilmer ushered in a sea change in the doctrine of arbitration enforcement: from that point forward, employment contracts were seen as fitting squarely within the arbitration mandate. Yet, subsequent Supreme Court precedent in this area, including Green Tree v. Randolph, did cite the importance of plaintiffs' ability to vindicate their statutory rights: arbitration of statutory rights will only be compelled "so long as the prospective litigant effectively may vindicate [his or her] statuto-

139. 500 U.S. 20 (1991).

140. Id. at 23 .

141. Id.

142. Id. at $23-24$

143. Id. at 34-35; see also David Sherwyn, Samuel Estreicher \& Michael Heise, Assessing the Case for Employment Arbitration: A New Path for Empirical Research, 57 STAN. L. REV. 1557, 1558 (2005).

144. Gilmer, 500 U.S. at 26 (alteration in original) (quoting Mitsubishi Motors Corp. v. Soler Chrysler-Plymouth, Inc., 473 U.S. 614, 628 (1985)).

145. See, e.g., Roberto L. Corrada, Claiming Private Law for the Left: Exploring Gilmer's Impact and Legacy, 73 DENV. U. L. REV. 1051, 1053-54 (1996) ("Gilmer himself should have felt secure in his argument that the Supreme Court's earlier decision in GardnerDenver was well on point."); Sherwyn, Estreicher \& Heise, supra note 143, at 1558 (noting that it spawned a debate amongst scholars).

146. Alexander v. Gardner-Denver Co., 415 U.S. 36, 49 (1974). 
ry cause of action in the arbitral forum," "'47 even in cases that ultimately upheld the arbitration conditions.

\section{B. Class Waivers: Banning Aggregate Claims}

Following the judicial approval of arbitration mandates in employment contracts, employers began more vigorously to import language into those clauses from commercial and consumer contracts to prevent parties from joining together in class and collective actions. ${ }^{148}$ Further, employers began challenging class arbitrations in agreements that were silent as to class treatment in the hope of forcing arbitration of individual claims without aggregate treatment. ${ }^{149}$

\section{When Silence in Contracts Is Given Legal Meaning}

When faced with an arbitration clause silent on class treatment, the Supreme Court first held that "ambiguity" exists as to the intentions of the parties and the arbitrator must decide whether the agreement was intended to prohibit class-wide arbitration. ${ }^{150}$ The plurality decision in Green Tree Financial Corp. v. Bazzle left many court watchers confused as to the state of the law of class waivers, but did at least confirm that courts foresee arbitrators as able to conduct class actions and that the FAA does not preclude class-wide relief, ${ }^{151}$ rejecting a posture taken by businesses. ${ }^{152}$

In response, the plaintiffs' bar renewed its attack on class arbitration waivers as unconscionable under state contract principles. ${ }^{153}$ Advocates argued that the inclusion of class waivers in standard adhesion contracts violated the common law contract doctrine prohibiting "unconscionable" or

147. Green Tree Fin. Corp. v. Randolph, 531 U.S. 79, 90 (2000) (alteration in original) (quoting Gilmer, 500 U.S. at 28); see also Mitsubishi Motors Corp., 473 U.S. at 637 \& n.19.

148. See Jean R. Sternlight, Should an Arbitration Provision Trump the Class Action? No: Permitting Companies to Skirt Class Actions Through Mandatory Arbitration Would Be Dangerous and Unwise, DISP. RESOL. MAG., Spring 2002, at 13.

149. Nora Lockwood Tooher, Plaintiffs Wrestle with Class Action Arbitration Bans, LAW. USA, Nov. 19, 2007, at 1, available at http://pubcit.typepad.com/clpblog/files/classarbarticle.pdf (noting that after Bazzle, "“[e]very big company rewrote their arbitration clauses to ban class actions"' (quoting Paul Bland of Public Justice)).

150. See Green Tree Fin. Corp. v. Bazzle, 539 U.S. 444, $451-54$ (2003).

151. See id. at 454-55 (Stevens, J., concurring) (arguing that FAA contained nothing to override state court's allowance of class arbitration).

152. Alan S. Kaplinsky \& Mark J. Levin, Excuse Me, But Who's the Predator? Banks Can Use Arbitration Clauses as a Defense, Bus. L. TODAY, May-June 1998, at 24, 24.

153. See, e.g., Laughlin v. VMware, Inc., No. 5:11 CV 00530 EJD, 2012 WL 298230, at *2 (N.D. Cal. Feb. 1, 2012); Massie v. Ralphs Grocery Co., No. B224196, 2012 WL 1078562, at *5 (Cal. Ct. App. Apr. 2, 2012). 
unfair agreements because they are so one-sided. ${ }^{154} \mathrm{~A}$ majority of courts examining the issue initially rejected this theory, holding that the contractual waiver of the "right" to bring a class action did not impact substantive rights and, therefore, was not unfair. ${ }^{155}$ However, in 2005, the California Supreme Court seemingly turned the tide when it held in Discover Bank v. Superior Court that because class waivers eliminate any incentive for plaintiffs to prosecute negative value claims, these waivers improperly limit defendants' exposure to damages when they appear in consumer contracts and are applied to allegations comprised of many small monetary claims. ${ }^{156}$ State courts around the country followed suit, many finding that class waivers were voidable when the cost of litigation dwarfed an individual plaintiff's potential recovery. ${ }^{157}$

The Supreme Court attempted to provide clarity to the class waiver doctrine in Stolt-Nielsen S.A. v. AnimalFeeds International Corp. ${ }^{158}$ There, petitioners were shipping companies sued by charterers for price fixing. ${ }^{159}$ The maritime contract contained an arbitration mandate but was silent as to class treatment. The parties stipulated that an arbitration panel would decide whether the contract permitted class arbitration. ${ }^{160}$ The arbitration panel determined that the expert testimony presented did not demonstrate an "inten[t] to preclude class arbitration," and, therefore, concluded that Bazzle and policy considerations meant that the clause should be read to permit class arbitration. ${ }^{161}$ The Supreme Court found that the arbitration panel "imposed its own policy choice" rather than "identifying and applying a rule of decision derived from the FAA or either maritime or New York law" and, therefore, it "exceeded its powers." 162 The Court did not shy away from taking on the issue itself, found the FAA controlling, and held that "a party

154. Myriam Gilles \& Gary Friedman, After Class: Aggregate Litigation in the Wake of AT\&T Mobility v. Concepcion, 79 U. CHI. L. REv. 623, 632 (2012).

155. See Randolph v. Green Tree Fin. Corp., 244 F.3d 814, 818-19 (11th Cir. 2001) (enforcing arbitration agreement so long as statute's substantive goals could be vindicated through arbitration); Snowden v. CheckPoint Check Cashing, 290 F.3d 631, 638 (4th Cir. 2002) (rejecting argument that agreement was unenforceable because of lack of class relief); Johnson v. W. Suburban Bank, 225 F.3d 366, 373 (3d Cir. 2000) (enforcing arbitration agreement and characterizing class action relief as procedural right); Arnold v. Goldstar Fin. Sys., Inc., No. 01 C 7694, 2002 WL 1941546, at *9 (N.D. Ill. Aug. 22, 2002) ("As a general matter, the right to bring a class action in federal court is a procedural right ...."); Sagal v. First USA Bank, N.A., 69 F. Supp. 2d 627, 631-32 (D. Del. 1999) (holding that availability of other enforcement mechanisms can obviate right to proceed by class action).

156. 113 P.3d 1100, 1108-09 (Cal. 2005).

157. See Horton, supra note 119 , at 462.

158. 130 S. Ct. $1758(2010)$.

159. Id. at 1765 .

160. Id. at 1765-66.

161. Id. at 1766 (alteration in original).

162. Id. at 1770 . 
may not be compelled under the FAA to submit to class arbitration unless there is a contractual basis for concluding that the party agreed to do so."163 Accordingly, the Court held that because the arbitration panel "imposed class arbitration" without explicit agreement amongst the parties, it reversed the decision of the arbitration panel allowing class arbitration. ${ }^{164}$

The takeaway for advocates in the employment sector was that arbitrators must make specific findings on the intent of the parties, but that class arbitration is not precluded when the agreement is silent on class treatment. Arbitrators applying Stolt-Nielsen examined the intent of the parties as controlling, witnessed by the agreement language and relationship of the parties, but understood Stolt-Nielsen to mean that the parties are not required to state an express agreement in order to authorize class arbitration. For example, in Benson v. CSA-Credit Solutions of America, Inc. ${ }^{165}$ an FLSA case, an arbitrator made three findings that supported class arbitration after examining the intent of the parties: (1) the arbitration clause contained broad language referring to "any dispute or claim relating to or arising out of the employment relationship;" (2) it specifically excluded disputes pertaining to trade secrets and proprietary information, and the doctrine of expressio unius est exclusion alterius implied that all other claims, including class claims, were included, especially in light of the fact that class waivers in employment were "not uncommon" in 2008, when the arbitration agreement was drafted; and (3) the respondent filed a motion to compel arbitration in civil court only after the claimant filed a collective action, ratifying that such class claims were subject to arbitration. ${ }^{166}$

\section{AT\&T Mobility LLC v. Concepcion: Protecting Defendants from Collective Action}

One short year later, the Supreme Court revisited the class waiver issue in $A T \& T$ Mobility LLC v. Concepcion. ${ }^{167}$ In Concepcion, siblings entered into a cell phone contract and received the advertised "free" cell phones, but, like 54 million other customers, were later charged sales tax on the phone in the amount of $\$ 30.22$ based on the retail value of the phone. ${ }^{168}$

163. Id. at 1775 .

164. Id.

165. Case No. 11-160-M-02281-08 (2010) (Meyerson, Arb.), available at http://www.nclc.org/images/pdf/unreported/Benson.pdf.

166. See id. at 6-9; see also Passow v. Smith \& Wollensky Rest. Grp., Inc., Case No. $\begin{array}{llllllll}11 & 160 & 00357 & 08 & (2010) & \text { (van Gestel, Arb.), available at }\end{array}$ http://www.foreclosuremediationfl.adr.org/si.asp?id=5490.

167. 131 S. Ct. 1740, 1744 (2011).

168. Id. 
They sued in federal court and their lawsuit was consolidated with a class action alleging false advertising and fraud. ${ }^{169}$

AT\&T then moved to compel arbitration pursuant to the arbitration clause in its standard service agreement, which included a class action waiver. ${ }^{170}$ Interestingly, the arbitration clause also lowered the expense of arbitration for complainants: (1) AT\&T paid all costs for nonfrivolous claims; (2) the customer chose whether to arbitrate locally in person, over the phone, or by written submission; (3) small claims court was available in lieu of arbitration; (4) arbitrators could award individual relief including injunctions and were not limited to compensatory damages; and (5) AT\&T was blocked from an award of attorneys' fees but would have to pay twice the complaint's attorneys' fees plus a minimum recovery of $\$ 7,500$ if the arbitrator awarded more than AT\&T's last settlement offer. ${ }^{171}$ The district court followed Discover Bank in finding the class waiver unconscionable under California state law and directed class arbitration. ${ }^{172}$ The Ninth Circuit affirmed. ${ }^{173}$

The Supreme Court reversed the Ninth Circuit in a 5-4 decision written by Justice Scalia, holding that the California Discover Bank rule was preempted by the FAA because it interfered with the federal goal articulated in the FAA of promoting arbitration. ${ }^{174}$ With regard to Section 2's saving clause, the Court held that although the "saving clause preserves generally applicable contract defenses, nothing in it suggests an intent to preserve state-law rules that stand as an obstacle to the accomplishment of the FAA's objectives."175 In so doing, Justice Scalia reasoned that the Discover Bank rule had categorically allowed claimants in any consumer case to demand class arbitration, which he found antithetical to the streamlined dispute resolution process that makes arbitration so favored. ${ }^{176}$ Specifically, the Concepcion Court found that "[a]rbitration is poorly suited to the higher stakes of class litigation" because: (1) "the switch from bilateral to class arbitration sacrifices the principal advantage of arbitration-its informality;" (2) "it is at the very least odd to think that an arbitrator would be entrusted with en-

169. Id.

170. Id. at $1744-45$.

171. Id. at 1744 .

172. Id. at 1745; Laster v. T-Mobile USA, Inc., No. 05cv1167 DMS (AJB), 2008 WL $5216255,{ }^{*} 14$ (S.D. Cal. Aug. 11, 2008) (citing Discover Bank v. Superior Court, 113 P.3d 1100,1108 (Cal. 2005)).

173. Concepcion, $131 \mathrm{~S}$. Ct. at 1745; Laster v. AT\&T Mobility LLC, 584 F.3d 849, 855, 857 (9th Cir. 2009) (finding that the Discover Bank rule was a "refinement of the unconscionability analysis applicable to contracts generally in California" and did not discriminate against arbitration in violation of the FAA (quoting Shroyer v. New Cingular Wireless Servs., Inc., 498 F.3d 976, 987 (9th Cir. 2007))).

174. Concepcion, $131 \mathrm{~S}$. Ct. at 1753.

175. Id. at 1748 .

176. Id. at 1748-50; see also Gilles \& Friedman, supra note 154, at 638. 
suring that third parties' due process rights are satisfied;" and (3) "class arbitration greatly increases risks to defendants."

Moreover, the majority belittled the dissent's concerns about the viability of small value claims as "toothless and malleable."178 The dissent, written by Justice Breyer, in turn, asked the interesting question: where did the majority get the idea that a fundamental arbitration attribute is individual arbitration? ${ }^{179}$

Aside from the questionable applicability of the Court's reasoning to FAA preemption of state law contract doctrine regarding the statutory wage rights of low-wage workers, much of the Court's reasoning is flawed when applied to prohibit aggregation of claims. First, arbitration's perceived informality is illusory for low-wage workers if they are unable to afford the significant costs of private arbitration. ${ }^{180}$ As articulated in Part IV of this Article, arbitration might provide a low-cost alternative if arbitration clauses were uniform and regulated to disperse the costs of arbitration. Second, the due process rights of absent class members are, well, absent in the case of FLSA collective actions where each worker must affirmatively opt in to the suit. Under Section 216(b), each worker is a plaintiff in the case that consents to join the litigation; therefore, due process concerns are negated. ${ }^{181}$ Lastly, the fact that the U.S. Supreme Court is concerned about the risks aggregate litigation poses for corporate defendants strikes this author as altogether inappropriate. The reality of the workplace is that workers have no meaningful opportunity to negotiate the terms of these take-it-or-leave-it arbitration and class waiver clauses. Instead, the terms of the "agreement" are presented to the worker as a fait accompli. For low-wage workers fearful of losing their jobs, and faced with a growing wage theft epidemic, the no-

177. Concepcion, 131 S. Ct. at 1751-52.

178. Id. at 1750 .

179. Id. at 1759 (Breyer, J., dissenting).

180. See generally Michelle Eviston \& Richard Bales, Capping the Costs of Consumer and Employment Arbitration, 42 U. TOL. L. REV. 903 (2011) (advocating an amendment in the FAA to require cost caps based on what plaintiffs would incur as a result of litigation as a method of preserving fairness); Stacy A. Hickox, Ensuring Enforceability and Fairness in the Arbitration of Employment Disputes, 16 WIDENER L. REV. 101 (2010) (discussing costs associated with arbitration as a potential barrier to fairness); Yongdan Li, Applying the Doctrine of Unconscionability to Employment Arbitration Agreements, with Emphasis on Class Action/Arbitration Waivers, 31 WHITTIER L. REV. 665 (2010) (analyzing the requirement of plaintiffs to pay costs in wage disputes as a basis for unconscionability). But see Samuel Estreicher \& Matt Ballard, Affordable Justice Through Arbitration, DiSP. RESOL. J., Nov. 2002-Jan. 2003 at 8,10 ("Accordingly, arbitration is not a device that deprives employee and consumer claimants of an opportunity to vindicate their rights, and may well be the only forum in which they can obtain a hearing. The fact that some costs are involved in arbitrating such disputes outside the publicly funded court system is not surprising, and, in fact, may be necessary to deter pursuit of frivolous claims.").

181. See 29 U.S.C. $\S 216$ (b) (2006). 
tion that the U.S. Supreme Court is mostly concerned with defendants' right to be free from potentially expensive litigation is disappointing. ${ }^{182}$

\section{The Post-Concepcion Split}

The Concepcion decision has drawn considerable comment from scholars ${ }^{183}$ and advocates, as well as other courts. ${ }^{184}$ While some business advocates have argued that Stolt-Nielsen and Concepcion stand for the proposition that class waivers are per se enforceable, other advocates argue that these cases read together stand for a more narrow point: that parties cannot be forced to arbitrate in class arbitration unless they agree to do so, and a categorical rule that classifies an entire set of cases as unconscionable violates the FAA. ${ }^{185}$

182. See David S. Schwartz, Understanding Remedy-Stripping Arbitration Clauses: Validity, Arbitrability, and Preclusion Principles, 38 U.S.F. L. REV. 49, 59-60 \& n.47 (2003) (barring class actions can operate as an exculpatory clause; no doubt such is the intent of the drafters of class action bans).

183. See, e.g., Sarah Rudolph Cole, On Babies and Bathwater: The Arbitration Fairness Act and the Supreme Court's Recent Arbitration Jurisprudence, 48 Hous. L. REv. 457, 491 (2011) ("Following Concepcion, remedies for consumers with low value claims will no longer be available through the judicial system. Thus, consumers and their advocates must turn to Congress for assistance with this major concern."); Jean R. Sternlight, Tsunami: AT\&T Mobility LLC v. Concepcion Impedes Access to Justice, 90 OR. L. REV. 703, 704 (2012) ("It is highly ironic but no less distressing that a case with a name meaning "conception" should come to signify death for the legal claims of many potential plaintiffs.... [Concepcion] is proving to be a tsunami that is wiping out existing and potential ... employment class actions.").

184. E.g., Green v. SuperShuttle Int'l, Inc., 653 F.3d 766, 769 (8th Cir. 2011) (“Concepcion convinces us the state-law-based challenge involved here suffers from the same flaw as the state-law-based challenge in Concepcion-it is preempted by the FAA. Consequently, Concepcion forecloses Green's claim that the district court erred in concluding the class action waivers were enforceable."); Brown v. Ralphs Grocery Co., 128 Cal. Rptr. 3d 854, 856 (Cal. Ct. App. 2011) ("[Concepcion] does not apply to representative actions under the [Private Attorney General Act], and thus the trial court correctly ruled that the waiver of plaintiff's right to pursue a representative action under the PAGA was not enforceable under California law."); Urbino v. Orkin Servs. of Cal., Inc., No. 2:11-cv-06456-CJC(PJWx), 2011 WL 4595249, at*11 (C.D. Cal. Oct. 5, 2011) ("[T] he purpose of [the Private Attorney General Act] 'contrasts with the private individual right of a consumer to pursue class action remedies in court or arbitration, which right, according to [Concepcion] may be waived by agreement so as not to frustrate the FAA-a law governing private arbitration. [Concepcion] does not provide that a public right, such as that created under the PAGA, can be waived if such a waiver is contrary to state law."' (quoting Brown, 128 Cal. Rptr. 3d at 861)).

185. Apalla U. Chopra \& David Lowe, Class Action Litigation and Arbitration After Wal-Mart v. Dukes and AT\&T v. Concepcion, in PraCTICING LAW INSTITUTE LitIGATION and Administrative Practice Course Handbook Series 175, 189-91 (2011); 1 JosePh M. Mclaughlin, MCLaughlin on Class actions: Law and Practice $§ 2: 14$ (8th ed. 2011); 3 W. Michael Garner, Franchise and Distribution Law and Practice § 17:80 (2012). 
The current legal landscape is seemingly split fairly evenly as to how this precedent relates to the small value wage theft claims of low-wage workers. One set of cases relies upon the federal substantive law of arbitrability and determines whether the plaintiffs are able to prove that they will be unable to vindicate their federal statutory rights if precluded from aggregating their claims. ${ }^{186}$ Following Concepcion, the Second Circuit in the In re American Express Merchants Litigation line of cases held that class waivers are unenforceable for claimants who are prosecuting federal statutory rights if enforcement of the waiver had the practical effect of prohibiting prosecution of those rights. ${ }^{187}$ The court held that the Supreme Court in Concepcion did not address this exact issue: whether a class waiver "is enforceable even if the plaintiffs are able to demonstrate that the practical effect of enforcement would be to preclude their ability to vindicate their federal statutory rights." 188 The Second Circuit's focus on substantive statutory protections stems from the Supreme Court's decision in Green Tree v. Randolph. The latest 2012 decision notes that the Concepcion decision does not mention Randolph and the federal arbitrability issue remains viable. ${ }^{189}$

Two other circuits disagree with the substantive statutory analysis and hold the opposite. The Third ${ }^{190}$ and Eighth ${ }^{191}$ Circuits have both held class waivers enforceable based on the holding of Concepcion. As the Third Circuit articulated in a FLSA collective action: "We understand the holding of Concepcion to be both broad and clear: a state law that seeks to impose class arbitration despite a contractual agreement for individualized arbitration is inconsistent with, and therefore preempted by, the FAA, irrespective of whether class arbitration is desirable for unrelated reasons." 192

A third recent development layers another interesting analysis to the question of class waivers for low-wage workers. The National Labor Relations Board (NLRB) ruled in January of 2012 that class waivers in arbitration clauses unlawfully restrict workers' right to engage in concerted action for mutual aid or protection pursuant to Section 7 of the National Labor Relations Act (NLRA).${ }^{193}$ In In re D.R. Horton, a national homebuilding

186. See Raniere v. Citigroup, Inc., 827 F. Supp. 2d 294, 304 (S.D.N.Y. 2011); Banus v. Citigroup Global Mkts., Inc., No. 09 Civ. 7128(LAK), 2010 WL 1643780, at *8-9 (S.D.N.Y. Apr. 23, 2010); Reid v. SuperShuttle Int'l, Inc., No. 08-CV-4854 (JG)(VVP), 2010 WL 1049613, at *4 (E.D.N.Y. Mar. 22, 2010).

187. In re Am. Express Merchs.' Litig., 554 F.3d 300, 320 (2d Cir. 2009); In re Am. Express Merchs.' Litig., 634 F.3d 187, 199 (2d Cir. 2011); In re Am. Express Merchs.' Litig., 667 F.3d 204, 218 (2d Cir. 2012).

188. In re Am. Express Merchs.' Litig., 667 F.3d at 212.

189. Id. at 216 (citing In re Am. Express Merchs. 'Litig., 634 F.3d at 197).

190. Quilloin v. Tenet HealthSystem Phila., Inc., 673 F.3d 221, 232 (3d Cir. 2012).

191. Green v. SuperShuttle Int'l, Inc., 653 F.3d 766, $767-70$ (8th Cir. 2011).

192. Quilloin, 673 F.3d at 233 (quoting Litman v. Cellco P'ship, 655 F.3d 225, 231 (3d Cir. 2011)).

193. In re D.R. Horton, 357 N.L.R.B. No. 184, 2012 WL 36274, at *1 (Jan. 3, 2012). 
company imposed an arbitration clause on its workers that included a class waiver. ${ }^{194}$ The NLRB held that such an agreement violates workers' rights, whether unionized or not, to engage in collective action, protected under Section $8(a)(1)$ of the NLRA, when it requires employees covered by the Act to sign an agreement that precludes them from bringing collective claims. ${ }^{195}$

Commentators agree that this decision could have sweeping implications for all workers, "from low-wage restaurant workers to well-paid employees on Wall Street," if allowed to stand. ${ }^{196}$

\section{HOW MANDATORY ARBitRation WITH Class WaIVERS AFFECTS LOW-WAGE WORKERS: WHERE DO WE GO FROM HERE?}

Scholars have noted a disturbing trend in recent Supreme Court jurisprudence: the systematic closing of the courtroom doors, especially for small claim litigants. ${ }^{197}$ For low-wage workers, the hurdles placed before class actions by the Wal-Mart v. Dukes ${ }^{198}$ and AT\&T Mobility LLC v. Concepcion ${ }^{199}$ cases reflect this judicial mindset and, as shown above, severely limit workers' ability to have their wage theft claims heard and addressed.

Of course, employers of low-wage workers could decide that allowing the arbitration costs of a multitude of individual claims is not an economically sound policy, and not altogether feasible, but, thus far, the evidence points in the other direction - towards advising corporate clients to take advantage of the "free pass" Concepcion provides. ${ }^{200}$ In the alternative, the

194. Id.

195. Id. at *9-10.

196. Steven Greenhouse, Labor Board Backs Workers on Joint Arbitration Cases, N.Y. Times (Jan. 6, 2012), http://www.nytimes.com/2012/01/07/business/nlrb-backsworkers-on-joint-arbitration-cases.html?_r=1\&. There are, however, several specific categories of workers excluded from the NLR $\vec{A}$, including: agricultural workers, public employees (including of the federal government), private-sector managers and supervisors, and workers whose employers have less than the annual revenue required for the NLRA coverage (usually $\$ 500,000$ but less in some industries). See 29 U.S.C. $\$ 152(3)$ (2006).

197. See generally Catherine Fisk \& Erwin Chemerinsky, The Failing Faith in Class Actions: Dukes v. Wal-Mart and AT\&T Mobility v. Concepcion (Univ. of Cal. Irvine Sch. of Law Legal Studies Research Paper Series No. 2011-54, 2011), available at http://papers.ssm.com/sol3/papers.cfm?abstract_id=1966624\#\#; Resnik, supra note 138.

198. For an analysis of how the Dukes case impacts class actions, and potentially wage and hour cases, see Moss \& Ruan, supra note 78.

199. 131 S. Ct. 1740 (2011).

200. See, e.g., Ronald W. Novotny, Drafting Class Arbitration Waivers After AT\&T Mobility v. Concepcion, DiSP. RESOL. J., Nov. 2011-Jan. 2012, at 40, 44 ("Finally, for employers who have not yet decided to implement a mandatory arbitration program, the Concepcion case provides another significant incentive for doing so."); Jay W. Waks \& Carlos L. Lopez, Challenging AT\&T Mobility v. Concepcion, DisP. RESOL. J., Feb.-Apr. 2012, at 6, 79 
Supreme Court could recall the original intent of Congress to allow aggregate litigation for promoting judicial efficiency and self-correct from the current course.

In the meantime, wage theft abuse continues to gain momentum and low-wage workers are left without adequate recourse. What options are left after Concepcion? Four possible avenues of redress remain: two within the current system of enforcement and two new proposals.

\section{A. Redress Within the Current System of Enforcement}

\section{Challenging Class Waivers as Precluding Vindication of Federal Statutory Rights}

Although at first blush the Concepcion decision seems to provide unqualified support to class waivers in mandatory arbitration contracts, the issue presented was narrowly tailored to federal preemption law, and analyzed a broad, categorical state rule. ${ }^{201}$ The decision, therefore, does not speak to the issue of federal arbitrability, which requires judicial consideration of imposing mandatory arbitration without class treatment on claimants who are precluded from vindicating their statutory rights-in this case, its effect on low-wage workers in prosecuting their wage rights. This "substantive rights" federal arbitrability analysis was not before the Court in Concepcion and at least one circuit court post-Concepcion has found that it requires federal courts to declare otherwise operative arbitration clauses unenforceable when enforcement would prevent plaintiffs from vindicating their statutory rights. ${ }^{202}$ Several courts prior to Concepcion found that when plaintiffs are prevented from doing so, the arbitration clause cannot stand or the class waiver is severable from the clause and class arbitration is ordered. ${ }^{203}$

A recent decision in the Southern District of New York illustrates how this applies in the FLSA context. In Raniere v. Citigroup, Inc., employees who processed mortgage applications brought an overtime FLSA collective

("[E]mployers may continue to enforce individual arbitration agreements and class action waivers with their supervisory and managerial employees.").

201. See Concepcion, $131 \mathrm{~S}$. Ct. at 1747 (discussing preemption); id. at 1746,1750 (discussing the "Discover Bank rule").

202. See In re Am. Express Merchs.' Litig., 667 F.3d 204, 214-16 (2d Cir. 2012).

203. See Kristian v. Comcast Corp., 446 F.3d 25, $47-48$ (1st Cir. 2006); Hadnot v. Bay, Ltd., 344 F.3d 474, 478 \& n.14 (5th Cir. 2003); Paladino v. Avnet Computer Techs., Inc., 134 F.3d 1054, 1062 (11th Cir. 1998); Sutherland v. Ernst \& Young LLP, 768 F. Supp. 2d 547, 549 (S.D.N.Y. 2011); Chen-Oster v. Goldman, Sachs \& Co., 785 F. Supp. 2d 394, 398 (S.D.N.Y. 2011); DeGaetano v. Smith Barney, Inc., 983 F. Supp. 459, 469 (S.D.N.Y. 1997). For severed clauses precedent, see Chen-Oster, 785 F. Supp. 2d at 410-11; Herrera v. Katz Commc'ns, 532 F. Supp. 2d 644, 647 (S.D.N.Y. 2008); and Beletsis v. Credit Suisse First Bos., Corp., No. 01 CIV. 6266(RCC), 2002 WL 2031610, at *6 (S.D.N.Y. Sept. 4, 2002). 
action against Citibank, alleging that they were misclassified as exempt from overtime. ${ }^{204}$ Citibank moved to compel arbitration based on an arbitration clause in the bank's employee handbook, which included a class waiver. ${ }^{205}$ The court first held that the right to proceed collectively under FLSA's $\S 216$ (b) cannot be waived as a matter of law, citing the legislative history of the Act, as well as Supreme Court FLSA precedent. ${ }^{206}$

The named plaintiffs in Raniere were not low-wage workers-their estimated FLSA overtime (though hotly contested) ranged from roughly $\$ 30,000$ to $\$ 150,000$ each, not including liquidated damages (which double the amount of overtime due) ${ }^{207}$ The court concluded that the plaintiffs were not precluded from arbitrating their claims individually because of the potential costs involved. ${ }^{208}$ Nonetheless, the court held the class waiver unenforceable because if any potential class member meets the burden of proving that her costs prevent her from effectively vindicating her rights in arbitration, the clause is unenforceable. ${ }^{209}$ "Any other reading would lead district courts down the rabbit hole of piecemeal litigation, confounding the twin advantages of reducing judicial caseload as well as costs to litigants." ${ }^{210}$ This line of precedent could find traction in the federal courts in FLSA actions and until the Supreme Court visits this issue specifically, could provide a vehicle by which low-wage workers can continue to have their claims aggregated and heard by the courts. ${ }^{21}$

Additionally, the NLRA provides another opportunity for low-wage workers to argue that they lose another set of important statutory rights: their right to engage in concerted action for mutual aid or protection, as provided for in $\S 7$. As the NLRB found in D.R. Horton, the right to proceed collectively in a wage action is intrinsic to their ability to engage in concerted activity: "Employees who join together to bring employment-related claims on a classwide or collective basis in court or before an arbitrator are exercising rights protected by $\S 7$ of the NLRA," specifically the right " "to engage in concerted activities for the purpose of collective bargaining or other mutual aid or protection."'12

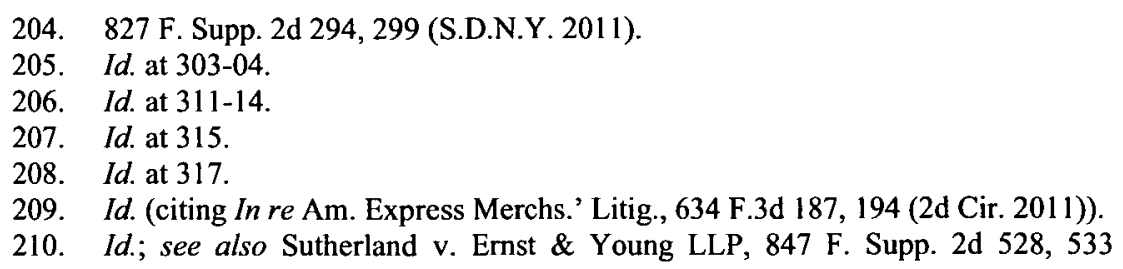
(S.D.N.Y. 2012).

211. However, even within the Southern District of New York, not all courts have agreed with this reasoning. See LaVoice v. UBS Fin. Servs., Inc., No. 11 Civ. 2308(BSJ)(JLC), 2012 WL 124590, at *6 (S.D.N.Y. Jan. 13, 2012).

212. In re D.R. Horton, 357 N.L.R.B. No. 184, 2012 WL 36274 , at *2-3 (Jan. 3, 2012) (quoting 29 U.S.C. $\S 157(2006)$ ). 
Accordingly, although applied in a small number of cases thus far, another avenue for low-wage workers is to argue that class waivers prevent them from enforcing their federal substantive statutory rights under the FLSA and NLRA and that federal courts should "harmonize" the FAA and these important employee protection statutes by applying the "vindication of statutory rights analysis of Randolph and related case[s]."213

\section{Renewed Public Enforcement of Wage Rights}

The Obama Administration has publicized its commitment to wage and hour enforcement, committing resources for hiring additional DOL WHD investigators, ${ }^{214}$ testing the waters for a new "regulatory philosophy" of requiring employers to audit themselves to ensure they are complying with the law, ${ }^{215}$ and voicing a renewed commitment to investigate the misclassification of employees and enforcement of wage and overtime laws. ${ }^{216}$ Because the latest report analyzing DOL enforcement measures is from $2008,{ }^{217}$ whether these measures are successful in reversing the tide of three decades of languishing wage and hour enforcement is unknown. However, with President Obama winning a second term, the DOL has an improved chance of receiving continued support. Moreover a bill introduced in Congress to address this problem, the Wage Theft Prevention and Community Partnership Act, died in committee. ${ }^{218}$

Some states and municipalities have recognized the "scourge" of wage thef $^{219}$ and responded with their own wage theft prevention laws. Just in the last five years, five states (California, Massachusetts, New Mexico, New York, and Washington) and two municipalities (San Francisco and MiamiDade County) have enacted such legislation, and three states (Texas, Illinois, and Maryland) and one city (Seattle) amended existing laws to shore up wage protections. ${ }^{220}$ Moreover, criminal penalties for wage theft are an-

213. See Gilles \& Friedman, supra note 154 , at 641.

214. Press Release, supra note 61.

215. Regulatory Agenda Narrative, supra note 62.

216. Press Release, U.S. Dep't of Labor, Statement of Hilda L. Solis, U.S. Sec'y of Labor, on Introduction of Legislation Regarding Issue of Misclassification (Apr. 22, 2010), available at http:// www.dol.gov/opa/media/press/whd/WHD20100541.htm.

217. U.S. DEP'T LABOR, supra note 50.

218. Wage Theft Prevention and Community Partnership Act, H.R. 6268, 111 th Cong. (2010), available at $\mathrm{http} / / \mathrm{www}$.govtrack.us/congress/bills/1 1 l/hr6268.

219. Toluse Olorunnipa, Lawmakers to Rework the Wage Prevention Program, Miami Herald (Jan. 27, 2012), http://www.miamiherald.com/2012/01/23/2610900/law makers-to-rework-wage-theft.html (chastising the Florida Retail Federation's efforts to scutthe the recently enacted Wage Theft Prevention Law in Miami-Dade county as un-American). 220. NaT'L Emp't LaW Project, WinNing Wage Justice, supra note 21 , at 20, 35, 45. 
other regulatory avenue some communities have taken or considered in combating abuse. ${ }^{221}$

In order for these ordinances and state laws to be effective, state and local communities have to be committed to enforcing these measures lest they become symbolic only. One team of scholars proposes that state Attorneys General (AGs) begin making use of their "parens patriae" authority to prosecute wage theft cases on a collective basis. ${ }^{222}$ By representing the interests of plaintiffs in wage and hour cases, state AGs can take on the role of "guardians of the public welfare" by collectively litigating against companies that inflict "broadly dispersed harms." 223

Another avenue for redress of wage theft is for local labor regulatory agencies to set informal hearings designed to address wage claims. One example that can be a model for other states is in California, where workers may file an administrative claim with the Labor Commissioner, who has the authority to conduct an informal hearing (called a "Berman hearing") and award lost wages. ${ }^{224}$ Importantly, either party can appeal the decision, but the employer is required to post a bond equal to the award, employees who prevail in the appeal are entitled to attorneys' fees, and the Labor Commissioner is required to represent employees who cannot afford counsel at the trial. ${ }^{225}$ Such measures protect low-wage workers in their attempt to recover lost wages but most critically, until recently, the California Supreme Court recognized that wage hearings before the Labor Commission are not subject to arbitration mandates. ${ }^{226}$ However, this holding is currently being relitigated post-AT\&T Mobility $L L C V$. Concepcion. ${ }^{227}$

In any event, although there may be future improvement in public enforcement, this is dependent on public budgets and election results, and is therefore not a reliable or complete solution to the continuing wage theft epidemic.

221. Seattle City Council Makes Wage Theft a Crime, SEATTLE TIMES (Apr. 25, 2011, 4:53 PM), http://seattletimes.com/html/politics/2014874499_wages $26 \mathrm{~m} . h t m l ;$ Anna Gorman, Labor Advocates Push for Law Making Wage Theft a Criminal Offense in L.A., Strauss L. GrouP, http://www.strausslawgroup.com/News/Wage-Theft-in-Los-Angeles.html (last visited Jan. 23, 2013). But see Colorado Lawmakers Reject 'Wage Theft' Bill, CBS DENVER (Feb. 28, 2012, 4:42 PM), http://denver.cbslocal.com/2012/02/28/colorado-may-criminalizewithholding-wages.

222. Gilles \& Friedman, supra note 154 , at $660-64$.

223. Id. at 675 .

224. CAL. LAB. CODE $§ 98$ (West 2012); see also Sonic-Calabasas A, Inc. v. Moreno, 247 P.3d 130, 133 (Cal.), vacated, 132 S. Ct. 496 (2011).

225. Moreno, 247 P.3d at 136-37.

226. See id. at 137-39.

227. Moreno, 132 S. Ct. 496 (remanding the case back to the California Supreme Court for further consideration in light of Concepcion). 


\section{B. Changing the Forum to Fit the Need}

\section{Making Arbitration Work for Low-Wage Workers}

Based on the limits of the above two avenues for relief, individual arbitration of wage claims might be the only avenue left for many low-wage workers. And if this is the case, what is the likelihood that wage theft claims can be successfully addressed in this forum?

Scholars are characteristically divided on the value of litigation versus arbitration as a forum for vindicating statutory rights. As Professors Eigen, Estreicher, Shewyn, and others have argued, federal court litigation is slow, expensive, and not particularly well tailored to the vindication of rights of individual workers, while arbitration is a forum that can be molded to fit the needs of low-cost claims. ${ }^{228}$

Despite those observations, for low-wage workers, arbitration is not any more welcoming than federal litigation, even with the relaxed evidentiary and procedural rules. Putting aside ability to take off time from hourly or temporary work with little job security, potential language barriers, and other barriers facing low-wage workers, arbitration is a dispute resolution process that has more in common with litigation than with informal resolution of negotiation and mediation: in order to win a claim, a claimant must present evidence and meet the legal burden, must convince the fact-finder of the facts and applicable law, and has little chance of appealing an incorrect verdict. Although cost, effort, and time spent are higher in federal court, it can also be high in arbitration because of the unfettered discretion of the arbitrator (for example, to order discovery, to entertain motions, to require legal briefings, or to hold an arbitration over several nonconsecutive days).

Accordingly, advocates combating wage theft need to make arbitration as accommodating to their claims as possible. First, advocacy for making arbitration clauses fair to workers is one starting point. Ironically, the arbitration clause in Concepcion can be a model. If used in the employment context, it would provide for: (1) the employer to pay all costs for nonfrivolous claims; (2) the claimant to choose whether to arbitrate locally in person, over the phone, or by written submission; (3) small claims court to be made available in lieu of arbitration; (4) arbitrators to award individual relief, including injunctions, not limited to compensatory damages; and (5) the employer being blocked from an award of attorneys' fees but having to pay twice the complainant's attorneys' fees plus a minimum recovery of

228. See, e.g., David Sherwyn, J. Bruce Tracey \& Zev J. Eigen, In Defense of Mandatory Arbitration of Employment Disputes: Saving the Baby, Tossing Out the Bath Water, and Constructing a New Sink in the Process, 2 U. PA. J. LAB. \& EMP. L. 73 (1999); Sherwyn, Estreicher \& Heise, supra note 143, at 1559-61. 
$\$ 7,500$ if the arbitrator awarded more than the employer's last settlement offer. $^{229}$

Next, a movement to make arbitration more cost friendly should include allowing non-lawyer advocacy in the forum. The ability to proceed pro se without an advocate even in a relaxed arbitration forum is outside the capabilities of many low-wage workers. Yet, attorneys are expensive, and it might be possible to present a viable and winnable wage theft claim without legal expertise. One can argue that wage claims are straightforward: did you work those hours? Were you paid minimum wage or the mandated overtime? With the burden for accurate time record keeping squarely on the employer, ${ }^{230}$ simple testimony from the complainant might be enough, especially if the low-wage worker is clearly outside the managerial or administrative exemptions.

Non-lawyer advocates, especially those with knowledge of the industry and worker population at issue, can be successful in stepping in to help navigate those waters and assist in marshalling the necessary evidence. One place to look for such advocates is in the growing number of worker centers in urban areas, which already organize and collaborate on important wage issues. The National Employment Law Project, Interfaith Worker Justice, Make the Road in New York, the Employment Law Center, and the UCLA Center for Labor Research and Education in Los Angeles are a few examples of successful organizations that are already working to provide support for low-wage workers. Adding arbitration advocacy on top of their already very full plates will take significant fundraising and training, but it could be an important priority and tool in the wage theft fight.

Unions are another potential source for wage theft prevention that might be retooled to include arbitration advocacy. Labor scholars have been examining for years the struggle unions are locked in to rebrand themselves and make them relevant in the twenty-first century. ${ }^{231}$ Professor and nowDeputy Secretary of Labor Seth Harris introduced a symposium centered entirely on workers' "Next Wave Organizing," referencing a new paradigm of labor law that represents the interests of workers in new and important ways. ${ }^{232}$ Legal advocacy-without attorney representation-in the arbitration forum could be another "next wave" tenet.

229. AT\&T Mobility LLC v. Concepcion, 131 S. Ct. 1740, 1744 (2011).

230. 29 U.S.C. § 211 (c) (2006).

231. See generally Fred Feinstein, Renewing and Maintaining Union Vitality: New Approaches to Union Growth, 50 N.Y.L. SCH. L. REv. 337 (2005); Charles Heckscher, Organizations, Movements, and Networks, 50 N.Y.L. SCH. L. REv. 313 (2005); Jim Pope, Next Wave Organizing and the Shift to a New Paradigm of Labor Law, 50 N.Y.L. SCH. L. REv. $515(2005)$.

232. See generally Seth Harris, Don't Mourn-Reorganize! An Introduction to the Next Wave Organizing Symposium Issue, 50 N.Y.L. SCH. L. REv. 303 (2005); Feinstein, supra note 231; Heckscher, supra note 231; Pope, supra note 231. 
One barrier to such innovation is labor's traditional rejection of mandatory arbitration of employment disputes. When mandatory arbitration began its ascendancy, labor leaders refused to participate in arbitration as a means of rejecting the compulsory, adhesive nature of the contracts at odds with collective bargaining. ${ }^{233}$ But, as Professor Roberto Corrada recognized, unions should not cut off their noses to spite their faces: "[I]t would be a shame if [unions'] stance ultimately inhibits transforming employment arbitration for the betterment of workers. After all, there is some potential for arbitration to provide better access, and thus more overall justice, for more workers, particularly those who are in the lower wage categories. ${ }^{\prime 234}$ Hopefully, today's unions are more open to arbitration as a forum for dispute resolution because with the proliferation of forced arbitration clauses comes the potential for wage theft recovery. And unions, with members and advocates committed to worker protection, might be a good fit for the forum.

However, the most significant barrier to non-lawyer advocacy is attorney practice rules. Assuming there are enough resources and capacity to train advocates to take on the role in assisting low-wage workers in arbitration, this restructuring of the arbitral forum would need to include a specific set of procedural rules allowing non-lawyer participation and, optimally, recognition from the Model Rules of Professional Conduct acknowledging this type of lay advocacy. ${ }^{235}$

Generally, states regulate the unauthorized practice of law (UPL) for their jurisdictions ${ }^{236}$ through state rules authorized by various sources: court rules, statutes, administrative regulations, judicial opinions, and the state's constitution. ${ }^{237}$ UPL rules regulate the delivery of legal services, which are defined in varying degrees of breadth and oversight. ${ }^{238} \mathrm{~A}$ universal definition of legal services is lacking, but there is some baseline agreement that legal services consist principally of preparing legal instruments, giving legal

233. See Roberto L. Corrada, The Arbitral Imperative in Labor and Employment Law, 47 CATH. U. L. REv. 919, 919-23 (1998).

234. Id. at 940 .

235. See Model Rules of Prof'L Conduct R. 5.5 (2012).

236. Federal UPL rules are narrowly tailored to restrictions on who may appear before the federal courts and federal administrative agencies. See Thomas J. Andersen, The Federal Practice Exception: Limitations on State Regulation of Federal Practitioners, 23 W. ST. U. L. REv. 281 (1996).

237. See Quintin Johnstone, Unauthorized Practice of Law and the Power of State Courts: Difficult Problems and Their Resolution, 39 WILLAMETTE L. REV. 795, 796-97 (2003).

238. For a recent comprehensive list of state definitions, see AM. BAR ASs'N TASK Force on the Model Definition of the Practice of Law, appendix A: State DEFINITIONS OF THE PRACTICE OF LAW (2003), available at http://www.abanet.org/cpr/modeldef/model_def_statutes.pdf. 
advice, and appearing in a representational capacity before an adjudicatory tribunal. ${ }^{239}$

Some states broadly interpret UPL standards to more heavily restrict the work of lay advocates in legal matters. ${ }^{240}$ Justifications for restricting lay advocates include: protecting the public against harmful and unscrupulous conduct, supplying disciplinary procedures to regulate those engaged in legal work, and keeping competition for lawyers to a minimum in exchange for their submission to regulation. ${ }^{241}$ Other states follow a more narrow definition of legal services to allow for more broad-based lay advocacy, which is in keeping with the ABA Commission's Nonlawyer Practice endorsement of lay advocates in $1995 .{ }^{242}$ Such an approach recognizes the unmet legal needs in communities of limited resources, in conjunction with efforts to improve access to justice. ${ }^{243}$

A campaign to liberalize UPL rules across jurisdictions could pave the way for workers to vindicate their wage rights in the arbitration forum. Because such rules are mostly governed by state laws, a model rule and updated strategy headed by the ABA or other interest group could be the best solution for mobilization. ${ }^{244}$

\section{Wage Claims Court}

A more novel potential avenue to address wage theft is through a judicial process specifically tailored to small wage and hour claims. Small claims courts are nothing new: the first one was created in 1912 and almost every state has created at least one type of small claims court since. ${ }^{245}$ While structurally different, all small claims courts are focused on resolving disputes with modest dollar amounts quickly and efficiently. Part of their value

\section{See id.}

240. See Soha F. Turfler, A Model Definition of the Practice of Law: If Not Now, When? An Alternative Approach to Defining the Practice of Law, 61 WASH. \& LEE L. ReV. 1903,1910 (2004).

241. See id. at 1916 n.46 (citing Derek A. Denckla, Nonlawyers and the Unauthorized Practice of Law: An Overview of the Legal and Ethical Parameters, 67 FORDHAM L. REV. 2581, 2581 (1999) (discussing the legal monopoly)).

242. See Suzanne J. Schmitz, What's the Harm?: Rethinking the Role of Domestic Violence Advocates and the Unauthorized Practice of Law, 10 WM. \& MARY J. WOMEN \& L. 295,305 (2004) (recognizing the ABA's role in advocating for more lay advocates in the domestic violence courts).

243. See Deborah L. Rhode, Professionalism in Perspective: Alternative Approaches to Nonlawyer Practice, 22 N.Y.U. REV. L. \& Soc. Change 701, 712 (1996); AM. BAR Ass'N

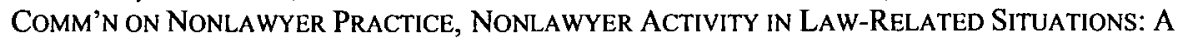
REPORT WITH RECOMMENDATIONS 45 (1995); Kendra Emi Nitta, An Ethical Evaluation of Mandatory Pro Bono, 29 LoY. L.A. L. REv. 909,913 (1996).

244. See Johnstone, supra note 237, at 842-43.

245. Bruce Zucker \& Monica Her, The People's Court Examined: A Legal and Empirical Analysis of the Small Claims Court System, 37 U.S.F. L. REv. 315, 317 (2003). 
is in taking a "'holistic approach[] to problem solving and dispute resolution," and "'allow[ing] maximum access to the courts by individuals unable to afford an attorney' by simplifying [the] rules of evidence and civil procedure." ${ }^{246}$ Many small claims courts have extremely low dollar limits, such as $\$ 1,000$. $^{247}$

Judicial reform activists have called for a reform of the small court system to address some of its shortcomings, including: (1) "[r]aising small claims dollar limits to $\$ 20,000$;" (2) “[a]uthorizing small claims judges to issue court orders," including injunctive relief, not just monetary damages; (3) "[e]xpanding small claims dispute resolution programs," such as mediation; (4) "protecting non-lawyer litigants;" and (5) "creating user-friendly courts," such as by expanding hours, adding advising programs, and increasing staff resources. ${ }^{248}$ Such initiatives would go a long way in making this forum a viable option for low-wage workers.

As currently structured, do low-wage workers' wage claims fit within most small claims courts across the country? Yes, if jurisdictional limits were increased specifically to reflect potential recovery of wage claims. But the difficulties inherent in navigating the differences in each jurisdiction of each court, including in jurisdictions with inadequate wage and hour state law protections, might mean that the current structure is a poor fit for the task. Another option might be a federal small court system, which some commentators have been calling for in order to gain relief from the expense and time associated with typical federal litigation. ${ }^{249}$

If dreaming of a federal small court system, one might as well dream big and consider the opportunity for a small court system tailored to wage claims. As a starting point, consider the family court movement. Recognizing a need for specialized courts to deal with the myriad issues facing families, in 1959, three working groups collaborated to produce the Standard Family Court Act, designed to assist states interested in creating family courts. ${ }^{250}$ Family courts grew out of the need to address the disproportionate effects of socioeconomic status and race in family law adjudication:

246. Anthony Ciolli, Lowering the Stakes: Toward a Model of Effective Copyright Dispute Resolution, 110 W. VA. L. REv. 999, 1023 (2008) (quoting Zucker \& Her, supra note 245, at 317; Marc Anthony Douthit, Humbling Experiences: Trials of Small Claims, LITIGATION, Fall 2000, at 27, 27).

247. Id. (citing Zucker \& Her, supra note 245, at 318).

248. James C. Turner \& Joyce A. McGee, Small Claims Reform: A Means of Expanding Access to the American Civil Justice System, 5 UDC/DCSL L. REv. 177, 177 (2000).

249. See Ciolli, supra note 246 , at 1023 (identifying federal copyright small claims courts); Robert P. Greenspoon, Is the United States Finally Ready for A Patent Small Claims Court?, 10 MINN. J.L. SCI. \& TECH. 549, 566 (2009) (advocating for the creation of a patent small claims court).

250. Barbara A. Babb, Fashioning an Interdisciplinary Framework for Court Reform in Family Law: A Blueprint to Construct a Unified Family Court, 71 S. CAL. L. REv. 469, 480 (1998). 
"“[C]ases involving families from the higher social strata rarely come to trial because the family has financial resources." 251

Then, still recognizing the unmet needs of families, the ABA stepped in and recommended the establishment of unified family courts in all jurisdictions. "Through a two-year project funded in late 1996 entitled 'Communities, Families, and the Justice System,'" the ABA helped establish unified family courts system in six cities. ${ }^{252}$ The bar recognized that having easier access to judicial relief, a judiciary trained and attuned to the specialized population's needs, and lower costs are essential in addressing that need.

A wage and hour court system-recognizing the unmet needs of America's poor working families-might be exactly what is required to address our wage theft epidemic. Given the parallel need for low-wage workers to vindicate their claims in court, a movement-a workers' wage rights movement-to address wage theft's pressing legal claims might find momentum if spearheaded by a collaboration of worker organizations, unions, practitioners, and scholars.

\section{CONCLUSION}

For low-wage workers who suffer wage theft, the dollars missing from their paychecks violate existing law and significantly impact the well-being of individuals, families, and communities. While this dire societal problem continues unabated, the Supreme Court continues "closing the courtroom doors" by allowing employers to force workers both out of court and into private arbitration, while simultaneously prohibiting aggregate claims. Such tactics work in confluence to silence wage claims, leaving far too many claims unheard while unscrupulous employers gain direct advantage.

This Article explains how the intersection of various procedural rulings has combined to prevent meaningful redress for wage theft and also proposes potential improvements. The courts might take corrective action by recognizing that the substantive statutory rights at issue trump arbitration and class waiver clauses in worker contracts. Perhaps the current promise of increased government enforcement of wage rights will come to pass. More ambitiously, unions and other worker activists could transform the arbitral forum by becoming legal advocates for low-wage workers to successfully prosecute individual wage claims in fair arbitration. Or, we might try a more

251. Id. at $472 \mathrm{n} .4$ (quoting JOHN HUBNER \& Jill WOLFSON, SOMEBODY ElsE'S Children: The Courts, THE Kids, and the Struggle to Save America's Troubled Families 141 (1996)); Monrad G. Paulsen, Juvenile Courts, Family Courts, and the Poor Man, 54 CALIF. L. REV. 694, 701 (1966) ("Because juvenile courts and family courts serve large numbers of the poor, the poor experience, in full force, the troubles raised by the problems of those courts.").

252. Babb, supra note 250 , at 474 . 
innovative approach to grant meaningful judicial access through creating a forum designed to address modest wage claims.

While mapping the procedural and substantive interconnections contributing to the wage theft epidemic will not alone suffice, it serves to reveal the role of law in confounding the delivery of justice to low-wage workers. Whether the claims are common law or statutory, at the state or federal level, in litigation or arbitration, those who toil at the bottom of the economic ladder deserve legal remedies for chronic and systemic violations of their right to be paid the wages they have worked so hard to earn. 
